\title{
DESL_VASTER
}

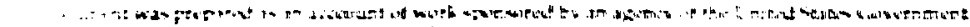

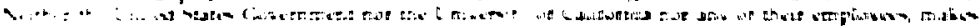

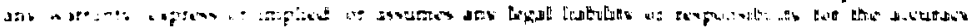

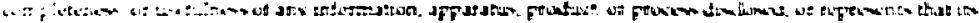

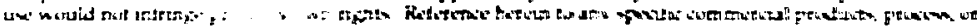

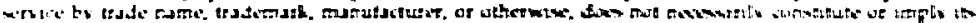

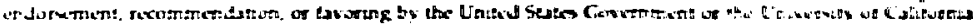

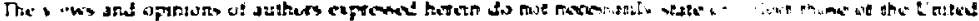

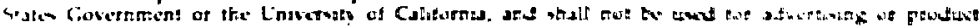

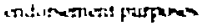

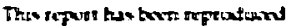

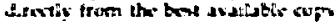

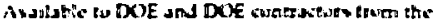

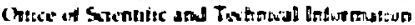

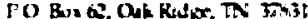

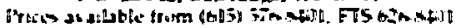

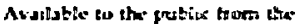

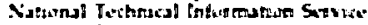

L'S Departmant at Corntratis:

525 ; Port Rasyal. RA.

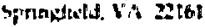

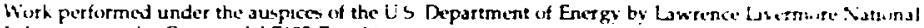
Luborstory undet Contract W.7405-Eng-48 


\section{Hydrology and Radionuclide Migration Program 1987 Progress Report}

Compiled by

Kenneth V. Marsh

Manuscript date: March 1991 


\section{Contents}

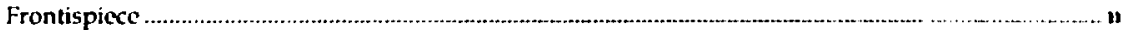

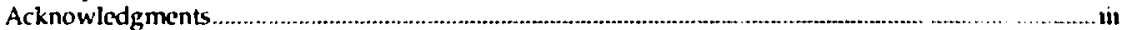

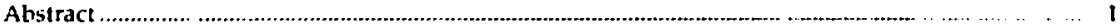

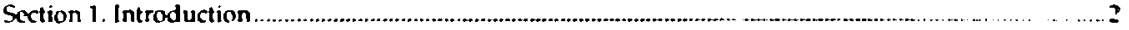

Section 2. Radionuclide Migration at the Cheshire Event Site …......................................................

Preliminary measurements on groundwater samples collected from a new well driliv approximately $100 \mathrm{~m}$ down the hydrologic gradient from the previous well demonsitate that we are dealing with transport of device-originated radionuclides by the natural hydrolingic regime. The results also tend to validate a proposed model of the fiow path and provede new: data on the rates of groundwater now and the behavior of the plume ol mixed racisonuetides.

Section 3. i.ienratory Studies of Colloid Migration in Fractured Mediu

Data collected from the Cheshire reentry hole indicated thal remosal of radionuclide-containıng particles onto fracture surfaces may be a mechanism that limits colloid migration in this regton. However, little is known aboul the factors controlling collotd deposition and relrase on real fracture surfaces in nulural environments. The L.C. Berkeley group has designed a laboratory experiment to quantify colloid retention and permeability alteration by the retained colloids.

References

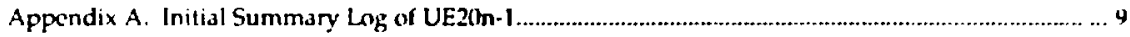

Appendix B. Summary of Initial Measurements on Water Somples from UE2On-1 ......... . . ......... 12

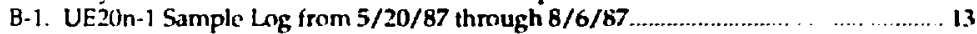

B-2 $\gamma$-Ray-Emilting Radionuclides in Water from UE20n-1.................. . . . . . . 18

B-3. Summary of Ficld Measurements at UE20n-1 ........................................ . . .19

B-4. Laboratory Measurements of Trace Cations and Anions in UE2On-I Water ........22

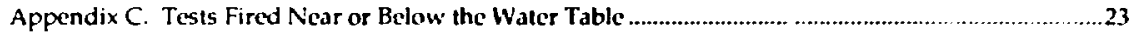

Appendix D. Tentative Proposal from Lamont-Doherty Geological Observalury............................... 27 


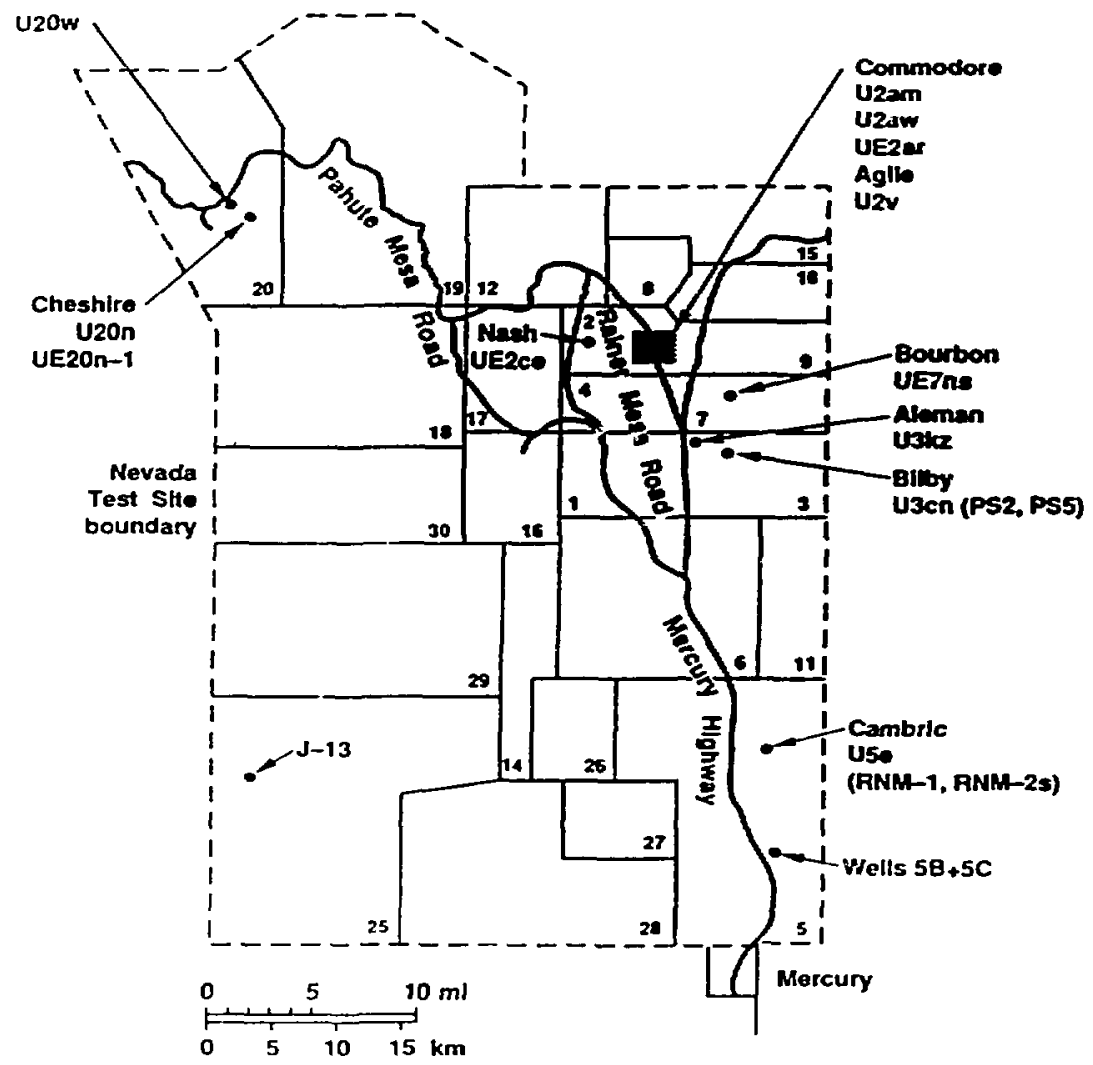

Frontispiece Locations of wells and Events relevant to the Hydrology and Radionuclide Migration Program. Small numbers indicate NTS areas. 


\section{Acknowledgments}

In the sections of this report that present data or interpretational results, the individuals who made significant scientific or technical contributions to the specific effort are lisicd as contributors. Many others, however, have provided general support, assistance, and advice important to the ovcrall report. We gratefully acknowledge the contributions of the following organizations and individuals:

Lawrence Livermore National Laboratory: C McGregor, G. Nimz, M. Taylor.

Los Alamos National Laboratory: J. Thompson and his coworkers in INC11.

Desert Research Institule (DRi): $R$ Jacobson and the professional and technical stiff al both the Reno and Las Vegas offices.

U.S. Geological Survey: Wayne Evert, C Savard, William Scott.

Reynolds Electrical and Engineering Co. Inc.: Environmental Science Department Personnel.

Department of Energy-Nevada Operations Office: D. Elke, J. Kitchen. 


\title{
Hydrology and Radionuclide Migration Program \\ 1987 Progress Report
}

\begin{abstract}
This report presents results from the Lawrence Livermore National Laboratory's participation in the Hydrology and Radionuclide Migration Program at the Nevada Test Site (NTS) during the fiscal year 1987. The report discusses initial data from a new well (UE20n-1) drilled at the Cheshire site; presents a description of a proposed laboratory study of migration of colloids in fractured media; lists data collected during the drilling and initial sampling of UE20n-1; and describes a tentative proposal fur work to be performed in FY88 by Lamont-Doherty Geological Observatory.

Groundwater sampled from the new well at the Cheshire site contains tritium concentrations comparable to those measured in previous years from locations above and within the Cheshire cavity. This presence of tritium, as well as several other radionuclides, in a well $100 \mathrm{~m}$ away from the cavity region indicates transport of radionuclides, validates a proposed model of the flow path, and provides data on rates of groundwater flow.

Previous work at the Cheshire site has shown that radionuclides are transported by colloids through fracturer! media. However, we have no data that can be used for predictive modeling, and existing theories are not applicable. While physical transport mechanisms of sub-micrometer colloids to defined mineral surfaces are well known, predictions based on well-defined conditions differ from experimental observations by orders of magnitude. The U.C. Berkeley group has designed a laboratory experiment to quantify colloid retention and permeability alteration by the retained colloids.

Two appendices include a summary log of activities at UE20n-1 from the start of drilling through the initial sampling, describe the samples collected, and present results of early field and laboratory measurements. A third appendix consists of a listing of all Tests at the Nevada Test Site between July, 1957, and October, 1987 that were fired near or below the water table. Appendix $\mathrm{D}$ is a tentative proposal from Lamont-Doherty Geological Observatory for work in the HRMF in FY88.
\end{abstract}




\section{Section 1. Introduction}

This report presents the results of technical studies conducted by the Lawrence Livermore National Laboratory (LLNL) as parl of the Hydrology and Radionuclide Migration Program (HRMP) at the Nevada Test Site (NTS). The program is intended to assess the potential for radionuclide migration away from the underground nuclear test cavities at the NTS, with particular emphasis on issues relating to ground water contamination and transport. The Frontispice shows the locations of the sites and wells studied at the NTS.

The project, which was initiated in 1974, continues as a multi-agency research project (LLNL, Los Alamos National Laboratory (LANL), the Desert Research Instutute (DRi) of the University of Nevada, and the U.S. Geological Survey (USGS)] coordinated and funded by the Nevada Operations Office of the U.S. Department of Energy (DoE-NVO).

The agencies involved in the project issue a variety of letter reports, technical reports, and scientific publications on asperts of HRMP studies. The most recent LLNL report gerumally available is the 1985-1986 Progress Report." The present report is a comprehensive account of LLNL activities and nesults. both dinxt and subcontracted, for the HRM Program for Fis?.

The report is organized on a topical basis. Section 2 summarizes our current investigutions into transport of radionuclides at the Chushir: site. We describe initial results of invesligations in a new well drilled to study Iransport of radionuclides from the detonation cavity down the hydrologic gradient. Section 3 describes the initialion of a laboratory experiment to sludy colloid migration in fractured media. The report concludes with appendices documenting work at the new Cheshire well, a list of detonations below. or near the waler table, and a tenlative proposal for work to be done by pursonnel from the Lamont-Doherty Ceological Observatory. 


\title{
Section 2. Radionuclide Migration at the Cheshire Event Site
}

\author{
R. W. Buddemeier, J. H. Rego, R. A. Failor, and K. V. Marsh
}

\section{Introduction}

The Cheshire detonation site (U20n, sce Frontispiece) at the NTS has been under investigation by the HRMP for several years and has been most recently described by Buddemeier.' The Event was fired in 1976 with an announced yicld in the range $200-500 \mathrm{kt}$. The detonation $\alpha$ curred beneath the water table in the iractured rhyolitic lavas of Pahute Mesa. Because of the event's size, its location in a relatively penneabie formation, and the proximity of the NTS boundary hydrologically down-gradient from the Event site, it was considered an excellent candidate for studies of radionuclide migration in groundwater.

\section{Site Studies}

In 1976, our efforts to sample water from the bottom of the postshot drillback hole below the cavity were only marginally successful. However, the hole was reconditioned in 1983 and substantial quantities of water were pumped from the cavity region. The radionuclide analyses showed activity levels well below those expected if the total yicld had remained in the vicinity of the cavity, leading to the suggestion that considerable migration might have occurred. United States Gerlogical Survey (USCS) investigations of U20a No. 2, a nearby well, indicated the existence of a vertical head gradient from below the shot point upwards to the permeable zones located at depths of 2400 to $2700 \mathrm{ft}$ and 2900 to $3100 \mathrm{ft}$. Groundwater could be expected to flow upward through natural or shot-induced fractures, then horizontally away from the shot area through permeable zones.?

A preliminary test of flow and migration hypotheses was possible because the slant-drilled reentry hole used for the study intercepted the water table and permeable zone above and downgradient from the cavity and outside the probable chimney region. In 1985, the well casing was plugged above the cavity and reperforated in the upper permeable zone. When sampling resumed at that level, it became apparent that concentrations were only' slightly lower than those observed in the cavily, and that radionuclides in both dissolved and particulate (colloidal) form had moved from the cavity to the upper sampling location. Detailed interpretations were not possible, however, because of concerns over the likelihoot of migration along the well casing annulus and the possibility that the sccono sampling point was within the range of blast-induced fracturing or radioruclide injextion.

Because of strong evidence that radionuclide migration was occurring. a second test well was drilled in May and June, 1987. Located approximately $100 \mathrm{~m}$ farther down-gradicnt frem the upper permeable zone sampling point in the rexntry well, the new well (UE2On-1) was of fset laterally to minimize the possibility of interaction with transport pathways associated with the older well. Drilling was planned and supervised by the four agencies involved in the HRMP (LLNL, LANL. DRI, and the USCS). LLNL was responsible for field analysis of formation water and drilling fuids for tritium and gamma-emilting nuslides.

Records for well UE20n-1 are included as Appendix A (initial summary log) and Appendix B (sample $\log$ and results of measurements during drilling, preliminary bailing, and initial pumping).

\section{Results}

Table 2-1 presents a summary of decaycorrected tritium activilies obs srved at the various sampling depths in the reentry hole and during the drilling of the new well. 1 ne tritium values observed during drilling are necessarily lower linuit, on the activity of the formation water berause of dilution with the non-tritiura-containing water used to make up the drilling foam.

Table 2-2 presents the maximi:m observed levels of ${ }^{99} \mathrm{Tc},{ }^{125} \mathrm{Sb}$, and ${ }^{137} \mathrm{Cs}$, the major nontritium radionuclides. Figure 2-1 show's the combined geolozy, hydrology, and geometry of the sampling points relative to the estimated cavitychimney region. Also depicted in Fig. 2-1 are the temperature profile measured in one of the postdrilling logging operations and a profile of 
Table 2-1. Groundwater tritium concentrations, corrected to detonation time, at various depths at the Cheshire site, $\mu \mathrm{Ci} / \mathrm{ml}$.

\begin{tabular}{|c|c|c|c|c|}
\hline \multirow[b]{2}{*}{ Depth, m } & \multicolumn{4}{|c|}{ Hole region and sampling dates } \\
\hline & $\begin{array}{c}\text { LE20n-1 } \\
\text { down-gradient } \\
5 / 87,7 / 87 \\
\end{array}$ & $\begin{array}{c}\text { C20nPS } \\
\text { above cavity } \\
11 / 85,5 / 85\end{array}$ & $\begin{array}{c}\text { Uanps } \\
\text { cavity } \\
\text { 10/8t, } 9 / 83\end{array}$ & $\begin{array}{c}\text { Limars } \\
\text { below cavity } \\
9 / 76 \\
\end{array}$ \\
\hline \multirow[t]{2}{*}{$6 n 0$} & 0.007 & & & \\
\hline & 0.003 & & & \\
\hline \multirow[t]{4}{*}{700} & 0.290 & & & \\
\hline & $0.620,0.580^{a}$ & & & \\
\hline & 0.670 & & & \\
\hline & 0.530 & & & \\
\hline \multirow[t]{2}{*}{800} & 0.460 & $0.4,0 . \$ 30$ & & \\
\hline & 0.4 & & & \\
\hline 900 & 0.030 & & & \\
\hline 1000 & 0.030 & & & \\
\hline \multicolumn{5}{|l|}{1100} \\
\hline 1200 & & & $0.5,0.620$ & \\
\hline 1300 & & & & 2.20 \\
\hline
\end{tabular}

a. After pumping $9.70 \times 10^{5}$ gallons.

Table 2-2. Maximum ${ }^{99} \mathrm{Tc},{ }^{125} \mathrm{Sb}$, and ${ }^{137} \mathrm{Cs}$ concentrations, corrected to detonation time, for various groundwater sampling locations at the Cheshire site, $\mu \mathrm{Ci} / \mathrm{ml}$.

Hole region, depths, anci sampling dates

\begin{tabular}{|c|c|c|c|c|}
\hline Radionuclide & $\begin{array}{c}\text { UE20n-1 } \\
\text { do::nn-gradient } \\
701-734 \mathrm{~m} \\
5 / 87, \quad 7 / 87\end{array}$ & $\begin{array}{c}\text { U20nPS } \\
\text { above cavity } \\
763-858 \mathrm{~m} \\
5 / 85\end{array}$ & $\begin{array}{c}\text { U20nPS } \\
\text { in cavity } \\
1206-1220 \mathrm{~m} \\
9 / 83 \\
\end{array}$ & $\begin{array}{c}\text { L'20nPS } \\
\text { below cavity } \\
1239-1272 \mathrm{~m} \\
9 / 76 \\
\end{array}$ \\
\hline${ }^{99} \mathrm{Tc}$ & $5.6 \times 10^{-8}(7 / 87)$ & $3.7 \times 10^{-8}$ & $4.8 \times 10^{-8}$ & - \\
\hline $125 \mathrm{Sb}$ & $\begin{array}{l}2.2 \times 10^{-6}(5 / 87) \\
2.3 \times 10^{-6}(7 / 87)\end{array}$ & $4.0 \times 10^{-6}$ & $7.2 \times 10^{-6}$ & $1.8 \times 10^{-6}$ \\
\hline${ }^{137} \mathrm{Cs}$ & $\begin{array}{l}<3.3 \times 10^{-8}(5 / 87) \\
<5.0 \times 10^{-10}(7 / 87)\end{array}$ & $7.4 \times 10^{-7}$ & $4.6 \times 10^{-6}$ & $5.1 \times 10^{-9}$ \\
\hline
\end{tabular}




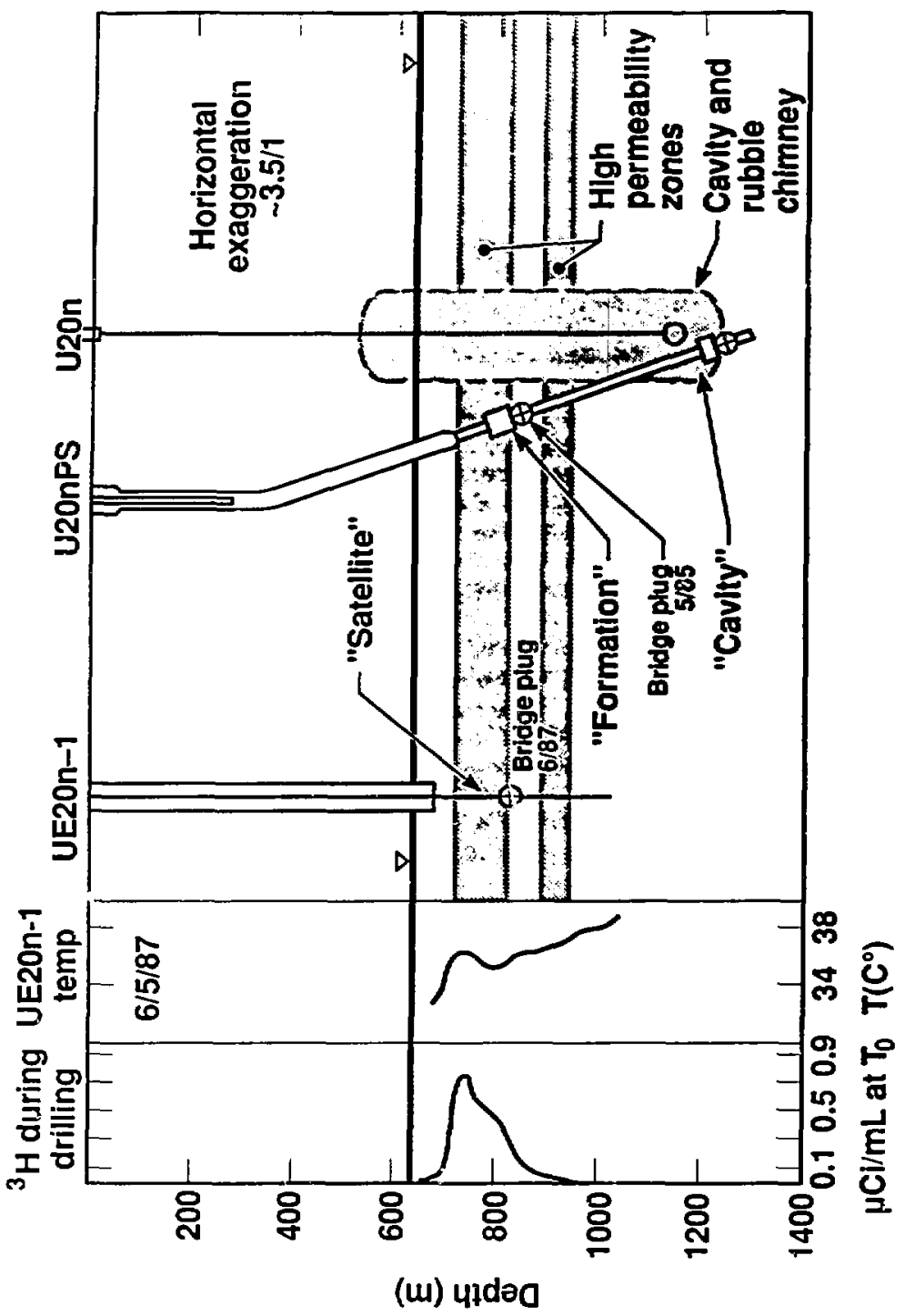

Figure 2-1. Vertical section showing Cheshire study locations, hydrogeology, and initial tritium and temperature observations in hole UE20n-1. 
the tritum concentratlons abetrsed surnes: the drilling.

Although the se result are prelinunury and turther work is planned, inperrtant mernidtum has already beve obtanew. ['ret. we note thal the tritium concentrstion maxumum snd the shallis:-

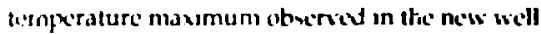
are concident and ceicur al approxamalely the upper besundary of the upper fermeable zone. Ihis provides stronge evidence in support ol the model that convertas ds -dricen warmer waster troni deeper zonco in Howilng upward through the carry and chimney, then horizemtal'; through the permeable labers. The lenperatures aterersid are consistent with other mearurenents by the L SGS in the area and do not appese to be directly attributable to restual heat from the detonstion.

Second, it is siginticant that at the new well fecation we have oberved the highest tritum actisity seren stnce the first poistsot wnple taken cuiside and dowse the cavety. Buth inslde and atwe the carly, intum concentratuons decreand

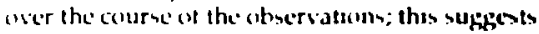
that we were leohmg at the tul of a contammant fulse, the peak of wheh had already passed both loculions. The hagher detivity obervid downfratient (nole that enly decay correcturns have t. Plade, and no dispersion corrections hate be'n applized) shows that the peak of the tritium arlavity pulse ha moved well out of the cavily: observatuns over tine will tell us whether the new location is on the leading or tralleng culge is that pulse. In wher case, the volume of formation material now shown to contasn significant levels of radionucides is large enugh to explain why the obsersed cavity concentratuons in 1963 were lower than predicted.

The data of Table 2-2 indicate that the general patter. cosserved in comparing the radionuclide concentrations between the cavity and first external sampling location is qualitatively consistent with the new observations: antimony and technetium are mobile contaminants, while cesium is much more strongly retarded in its movement through the formation. If we estimate rates of water movement by assuming that tritium is a conservative tracer and that vertical equilibration of the cavity and chimney took place promptly after the Event, then horizontal flow velocity (and con-

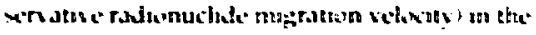

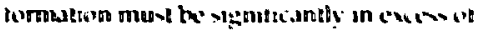

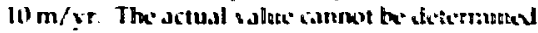
whthout identilying the feddsng atge en the cont.minant plume ard the distition of the nimbt ropid ilow:

All four Jyenches aghend that we should noy vigorously punp or surge the nest well, bul rather, in an altenipt to oberene as marly as pussible natural migraluen rates, we shoul.t install a low-volume pump and collevt sumples wh a ht-

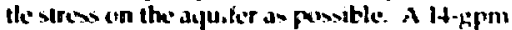
pump was anslalked as the thet solutien tur cullicting reproxentuluxe simples whth munemun disturbunes. Hionteind to collext sunples over the next lisw yedrs with nunimum pumping to try to delermine whether we are chersing the irout. midule, cr tasl ef the plunk.

\section{Conclusions}

These initul results are iniporlunt for the following reasins.

- We conclude that we ste dealing with Iranspirt of devicieriringled racesunuclides by the nutural hydrolingic regime.

- We have oblained importent new dala on the rates of groundwilter flow and the behavior of the plinine of mixed radionuclides.

- We can use these data lo validatio a propeised mindel of the flow path.

Addational work is planmed and in progress the charactenze the giechemistry, hydrology, and - nuclide concentralions and spectation at the new well site. Adjitten of this third sumpling point, particularly bex.su et of its valudation of the results obtained at the earlier sites, will permut more detailed interpretation of the interactions between the aquifer and the contaminsted water. We anticipate that tiue combunation of the water studies with charactenze tion of the core's and cutling samples obtained during drilling will permit us to extract iniportant data from what in essentially the first documented study of largescale radionuclide transport in a dexp hard-rock envoronment. The results will be significant to broad areas of geochemistry and waste dis?ousal as well as to the HRMIP. 


\title{
Section 3. Laboratory Studies of Colloid Migration in Fractured Media
}

\author{
James $R$. Hunt \\ Deparfrient of Civii Engineering \\ Unioersity of Califomia \\ Berkeley, Califormia
}

\section{Introduction}

The experimental results of the colloid intesiigation at the Cheshire stte were discussed in detail in last year's HRMP report, ${ }^{1}$ and a bricf summary of that work will be useful as an introduction to our planned laboratory studics.

Large-volume water samples collected from the "cavity" and "formation" locations in the directirnal-drilled reentry hole were processed at LLNL by serial-filtration and ultrafiltration techn:ques. The results showed that some radionuclides produced during detonation were present both in solution and associated with colloidal muterials at the tre'o locations. The data also showed that cesium adsorption to colloids al the Chyshire site followed previously-determined isotherme. Geochemical modeling, $X$-ray diffraction studies. and $X$-ray fluorescence analyses vere all consisten! in supporting the existence and transport of colloids from the cavity to the external formation. This is the first field demonstration that radionuclides are transported by colloids through fractured media.

The Cheshire data from the neentry hole indicated that for the strongly-sorbed radionuclides, their total activity at the formation location was only $2.5 \%$ of the cavity activity. This indicates removal of colloids from suspenjior onto fracture surfaces and may be a mechanism that limits colloid migration in the region. Still, mobility of strongly-sorbing specics hundreds of meters is entirely unexpected using conventional models that are based on the assumption that sorbed species are immobile.

The existing data on radionuclide migration at the Cheshire site cannot be used for predictive modeling, nor are existing theories applicable. The t $w$. major prob!ems are to identify the mobile colloid: at Cheshire and then to develop predictive models for their mobility in fractured media. Identification of colloids collected from various locations within the NTS is being undertaken by Dr. Roger Jacobson (DRI), while the U.C. Berkeley group has identified critical experimenta' mea- suremenis nexded to qusntify collowd migralwen im fractured madis.

\section{Laboralory Eiperiments}

Experimental data coliexted in the Lbosaton: are cssential because arailabt" theoriss for colletd removal are inadequale. The physical transpont mechanisms of sub-micrometser colkids to delined mincelal surfaces are well known and exper. imontally verified. However, under natural wister condilions, colloid collusion with mincral surfacts only occasionally results in altachmeni because of ckeirostatic npulsion betwern purlicie and min. cial suriaces. Theoretical p adictions for etectzostatic effects under well-defind conditions differ trom experimental obseryations by orders-ofmognitude. Furthcrmore, fracture surlaces are covered with sccondary mintrols produced by wealhering reactions, and thus do not represint ideal, fat mincral surfaces. Celloid deposition on surfaces containing previously depasited colloids on sccondary minctal growths is the important issue on fong-term transport in natural environmenis, but no applicable theory or experimenlal data are avoilable.

Considering the above, the U.C. Berkeley group has designed a laboratoy experinuent to quantify colloid relenloon and permeability alteration by the retained colloids. The experimes:initially will be conducted by flowing a dilute suspension of kno:n :lay colloids un a narrow $(\leq 1 \mathrm{~mm}$ ) channel between two parallel gluss plates. Wilt time, a deposit of clay colloids will begin to plug the char,nei until an cquilibs ium is reached when particles are-no longer relained because hyd. odynamir shear forces exered colloid-deposit attachment forces. Colloid retention over fime and at different locations wiil be monitored by passing a light beam through the glass plates. The independent parameters of inlerest are imposed flow rate, aqueous solution composition, and channel wioth. The measurements will determine colloid mass retention, and permeability alteration. It is expected that predictric, although empirical. 
relationships will result between these measures of clogging and the structural characterization of colloid aggreqates through rheological measurements.

The above experimental design will be tested with a well-characterized elay mineral. probably kaolinite, during the coming year. At the completion of these experiments, a sufficient supply of NTS colloids may be available te permit using them in the exporimental apparatus: On completion of the caperimcnt, we will undtrstond the mechanism of colkid retintion and permeability alketation in fraclured mudiw. We can then address the important issues of cellowd release from fracture surfaces followin: detonations and issues of regional colkind migralion through fracture networkx

\section{References}

1. R. W. Buddemeier, Hydrology und Radionuclide Migration Progiten 1955-19s6 Prostess Ruprt. Lawrence I jvermore National Laboratory, Litermore, Califomia, UCRL 5379 (1988).

2. R. K. Blankennagel and J. E. iVeir, Jr., Geohydrology of the Eastern Part of Patule Mase, Netruts Test Site. Nye Cownty. Nezada, United States Geological Survey Professional Paper 712-B. Unilud Swtes Government Printing Office, Washington, D.C. (1973).

3. R. Gunnink and J. B. Niday, Computcrizel Quantitalixe Analysis by Camma-Ray Spatrontety. Lawrence Livermore National Laboratory, Livermore, California, UCRL-51061 (1972). 


\section{Appendix A \\ Initial Summary Log of UE20n-1}

This sum: sary $\log$ covers the period from the stant of drilling for the surface castag on $5 / 15 / 87$ through initial pumping on 9/17/87. Corrections and additions to this log have bern solicitid from the other HRMP organizations, and a final revision will be published by the USCS. The dat, compiled by: USCS, are included here as a convenient ane-source working reference of the status of the well when various samples were collected.

Note that the flow meter was not instalked until $7 / 22 / 87$, so the now volumes are eslimates thal include the volume before $7 / 22 ; 87$.

Table A-1. Initial summary log of UE20n-1.

\begin{tabular}{|c|c|c|c|c|c|}
\hline Date & Time & Activity & $\begin{array}{l}\text { Meter } \\
\text { reatias } \\
\text { eal }\end{array}$ & $\begin{array}{c}\text { Incremental } \\
\text { volume: } \\
\text { inl }\end{array}$ & $\begin{array}{c}\text { Tolal } \\
\text { volume." } \\
\text { pal }\end{array}$ \\
\hline $05 / 15 / 87$ & & Drill 17-1/2" hole and set $13-3 / 3^{\circ}$ easing & - & - & - \\
\hline $05 / 18 / 87$ & & Set up to drill & - & - & - \\
\hline $05 / 19 / 87$ & & Begin drilling through surface casing cement & - & - & - \\
\hline $05 / 20 / 87$ & 0000 & 591 feet & - & - & - \\
\hline $05 / 21 / 87$ & & $\begin{array}{l}\text { Setting up bollom hole assembly to bring hole } \\
\text { back into line }\end{array}$ & - & - & - \\
\hline $05 / 22 / 87$ & 0000 & 1392 feet & - & - & - \\
\hline \multirow[t]{5}{*}{$05 / 23 / 87$} & 0000 & 1952 leet & - & - & - \\
\hline & 0905 & 2325 feel & - & - & - \\
\hline & 0929 & Blow hole and collect samples & - & - & - \\
\hline & 1300 & Out of hole & - & - & - \\
\hline & 1400 & $\begin{array}{l}\text { Start logging (fluid density, caliper, indurtion. } \\
\text { gamma) }\end{array}$ & - & - & - \\
\hline \multirow[t]{2}{*}{$05 / 24 / 87$} & & Oo spikes in gamma log - OK to case to 2300 it & - & - & - \\
\hline & 1000 & $\begin{array}{l}\text { Start running 9-5/8n casing into hole, casing nun } \\
\text { to } 2283 \text { feet, cement hole }\end{array}$ & - & - & - \\
\hline $05 / 25 / 87$ & & Holiday & - & - & - \\
\hline $05 / 26 / 87$ & & $\begin{array}{l}\text { Cement job resulted in cement not being } \\
\text { pumped into annulus as expected; because of } \\
\text { poor tacking strength, drilling of the cement } \\
\text { proceeded slowly. }\end{array}$ & - & - & - \\
\hline \multirow[t]{6}{*}{$05 / 27 / 87$} & 0000 & 2103 feel still drilling out cemen! & - & - & - \\
\hline & 1140 & 2407 feet - trip out for coring & - & - & - \\
\hline & 1600 & Trip in with core barrel & - & - & - \\
\hline & 1800 & Blow hole & - & - & - \\
\hline & 1845 & Start coring & - & - & - \\
\hline & 2010 & Blow hole and colled somple & - & - & - \\
\hline \multirow[t]{4}{*}{$05 / 28 / 87$} & 0330 & 2422 feet - Irip oul with core barrel & - & - & - \\
\hline & 0600 & Core on table & - & - & - \\
\hline & 1430 & Trip into hole & - & - & - \\
\hline & 1615 & Blow hole and culleci sample & - & - & - \\
\hline \multirow[t]{4}{*}{$05 / 29 / 87$} & 0213 & Trip in with core barrel & - & - & - \\
\hline & 0400 & Blow hole & - & - & - \\
\hline & 0518 & Start coring & - & - & - \\
\hline & 0745 & 2654 feet - trip out with core barrel & - & - & - \\
\hline
\end{tabular}




\begin{tabular}{|c|c|c|c|c|c|}
\hline Dale & Time & Activity & $\begin{array}{l}\text { Meter } \\
\text { reading } \\
\text { gal }\end{array}$ & $\begin{array}{c}\text { Incremenlal } \\
\text { volume. } \\
\text { gal }\end{array}$ & $\begin{array}{c}\text { Total } \\
\text { solume, } \\
\text { gal }\end{array}$ \\
\hline \multirow[t]{3}{*}{$05 / 29 / 87$} & 1000 & Core on Iable & - & - & - \\
\hline & 1330 & Trip into hole & - & - & - \\
\hline & 1355 & Blow hole & - & - & - \\
\hline \multirow[t]{9}{*}{$05 / 30 / 87$} & 0026 & 2877 Ieel & - & - & - \\
\hline & 0634 & 3003 leel - trip out tor coring & - & - & - \\
\hline & 1000 & Trip in with core barrel & - & - & - \\
\hline & 1130 & Blow hole & - & - & - \\
\hline & 1245 & Start coring & - & - & - \\
\hline & 1600 & 3017 feet - Irip out wilh cote barrel & - & - & - \\
\hline & 1745 & Core on table & - & - & - \\
\hline & 1830 & Trip into hole & - & - & - \\
\hline & 2121 & Blow hale & - & - & - \\
\hline \multirow[t]{4}{*}{$05 / 31 / 87$} & 0200 & 3066 feet & - & - & - \\
\hline & 1604 & 3300 feet & - & - & - \\
\hline & 1830 & Sturt gyra survey & - & - & - \\
\hline & 2310 & Blow hole & - & - & - \\
\hline \multirow[t]{2}{*}{$06 / 01 / 87$} & 0200 & Finish pulling pipe from hole & - & - & - \\
\hline & 0500 & Sturt logging & - & - & - \\
\hline $06 / 02 / 87$ & & Still running logs & - & - & - \\
\hline $06 / 04 / 87$ & & L'SGS barrel samples & - & - & - \\
\hline $06 / 05 / 87$ & & DRJ logging and barrel samples & - & - & - \\
\hline $06 / 08 / 87$ & & DRI logging and barrel samples & - & - & - \\
\hline $06 / 09 / 87$ & & Special gravily log & - & - & - \\
\hline $06 / 10 / 87$ & & $\begin{array}{l}\text { Set drillable bridge plug al } 2842 \text { teet; sand plug } \\
\text { on : up of bridge plug }\end{array}$ & - & - & - \\
\hline $06 / 10 / 87$ & 2315 & Cement on top of sand & - & - & - \\
\hline $06 / 11 / 87$ & & $\begin{array}{l}\text { Bigin running dual casing string set Moyno } \\
\text { pump and sucker rods }\end{array}$ & - & - & - \\
\hline $06 / 12 / 87$ & 1015 & $D / w^{b} 2033.65$ & - & - & - \\
\hline \multirow[t]{2}{*}{$06 / 22 / 87$} & 1020 & D/W 2032.35 & - & - & - \\
\hline & 1307 & Pump on & - & - & - \\
\hline \multirow[t]{2}{*}{$06 / 23 ; 87$} & 0925 & Pump off & - & - & 17,000 \\
\hline & 1125 & $\mathrm{D} / \mathrm{W} 2032.40$ & - & - & - \\
\hline $06 / 26 / 87$ & 1000 & $\mathrm{D} / \mathrm{W} 2032.6$ & - & - & - \\
\hline $07 / 02 / 87$ & 1130 & $D / W 2032.45$ & - & - & - \\
\hline \multirow[t]{2}{*}{$07 / 07 / 87$} & 1000 & $D / W 2032.65$ & - & - & - \\
\hline & 1055 & Pump on & - & - & - \\
\hline \multirow[t]{3}{*}{$67 / 09 / 87$} & 1225 & $D / W 2036.25$ & - & - & - \\
\hline & 1225 & Pump off & - & 21,000 & 38,000 \\
\hline & 1227 & $\mathrm{D} / \mathrm{W} 2032.5$ & - & - & - \\
\hline $07 / 13 / 87$ & & DRI logging & - & - & - \\
\hline $07 / 14 / 87$ & & DRI logging and barrel samples & - & - & - \\
\hline \multirow[t]{2}{*}{$07 / 20 / 87$} & & DRI logging and barrel samples & - & - & - \\
\hline & & Pump on & - & - & - \\
\hline \multirow[t]{2}{*}{$07 / 21 / 67$} & & Pump off (sometime during graveyard) & - & 15,000 & 53,000 \\
\hline & & LANL samples & - & - & - \\
\hline
\end{tabular}


Table A-1 (continued).

\begin{tabular}{|c|c|c|c|c|c|}
\hline Date & Time & Activity & $\begin{array}{c}\text { steter } \\
\text { reading } \\
\text { gal }\end{array}$ & $\begin{array}{c}\text { Inctiemenlal } \\
\text { volume, } \\
\text { gal }\end{array}$ & $\begin{array}{c}\text { Total } \\
\text { volume. } \\
\text { gal }\end{array}$ \\
\hline $07 / 22 / 87$ & & Pump on, flow meter installed & - & - & - \\
\hline $07 / 23 / 87$ & 0950 & Pump off, DRI logging & - & 50,718 & 103,718 \\
\hline \multirow[t]{5}{*}{$07 / 27 / 87$} & 1022 & Pump on & 125,470 & - & - \\
\hline & 1024 & & 125,498 & - & - \\
\hline & 1025 & & 125,509 & - & - \\
\hline & 1045 & $(125,790 \mathrm{G}-125,470 \mathrm{G} / 23 \mathrm{~min}=14 \mathrm{GPM}$ & 125,790 & - & - \\
\hline & 1045 & $\begin{array}{l}\text { Pump off, needs repacking- Repack pump. } \\
\text { install flowmeter, pump on }\end{array}$ & - & - & - \\
\hline $07 / 28 / 87$ & & $\begin{array}{l}\text { Moyno pump breaks down, noticed during } \\
\text { early moming check }\end{array}$ & - & - & - \\
\hline \multirow[t]{3}{*}{$83 / 03 / 87$} & & Moyno pump repairs, sucker rod failed & - & - & - \\
\hline & 1403 & Pump on & - & - & - \\
\hline & 1441 & Water al wellhead & - & - & - \\
\hline $08 / 04 / 87$ & 1800 & Pump off & 176.773 & 51,303 & 155.021 \\
\hline $08 / 06 / 87$ & 1145 & D/W 2033.15 & - & - & - \\
\hline $08 / 24 / 87$ & 1120 & D w 2033.15 & 179.756 & - & - \\
\hline $09 / 01 / 87$ & 1130 & D/w 2032.9 & - & - & - \\
\hline \multirow[t]{3}{*}{$09 / 06 / 87$} & 1020 & D/W 2033.3 & - & - & - \\
\hline & 1055 & Pump on & 179,756 & - & - \\
\hline & 1300 & Pump off & 180,920 & 1,144 & 156,165 \\
\hline \multirow[t]{2}{*}{$09 / 11 / 87$} & 1000 & Pump on & 180,963 & - & - \\
\hline & 1230 & Pump off & 182,551 & 1,588 & 157,733 \\
\hline \multirow[t]{3}{*}{$09 / 17 / 87$} & 1020 & D/w 2032.5 & - & - & - \\
\hline & 1022 & Pump on & 182,532 & - & - \\
\hline & 1205 & Pump off & 183,452 & 920 & 158,673 \\
\hline
\end{tabular}

a. Incremental volume estimaled before $\mathbf{9} / \mathbf{4 / 8 7}$

b. $D / W=$ depth to standing water, feet 


\section{Appendix B \\ Summary of Initial Measurements on \\ Water Samples iroin UE20n-1}

B-1: UE20n-1 sample log - A descriphon of all samples collectod from start of drilling on $5 / 20 / 87$ through the final pumping on $8 / 6 / 87$.

B-2: Laboratory measurements of y-ray-emilting radionuclides.

B-3: Field measurements conducted during the drilling, bailing and pumping seyuences.

B-4: Laboratory measurements of trace cations and anions. 


\section{Appendix B-1. UE20n-1 Sample Log from 5/20/87 through 8/6/8?}

\section{Background}

We felt that it would be useful to make measurements of tritium, y-ray-emilting radionuclides, bro. mide, and detergent concentrations in the field as aids in making decisions dunng drilling ant initial sampling of UE20n-1. We equipped a trailer with a simple, single-sample, 2-channel liquid scintillation counter and two intrinsic germanium rdetectors, one in "up-looker" configuralion, the other as a "sidxlooker." Output signals from each detector were processed by an ND-66 analyzer, and stoned on disk. for spectral analysis, in the field, on an LSI-11 processor using GRPANAL, a small scale version of GAMANAL. ${ }^{3}$ The side-looker was used for counting core samples and rock chips, moslly in a surney mode. Although counting efficiencies for cone and chip samples were not well known due to their irregular stze and shape, this had no effect on isotope identification, and quantitalive determinations of radionuclide concentrations in sucis samples was of limited utility at best. Furthermore, from a practical stand point, no artificial radionuclides were detected in any core or chip sample; however, counting times were necessarily short, a few hours to a day at most, due to the number of samples we had to proxess. The up-looker was used mostly for counting water samples in Marinelli beakers, but could also be : ised to, survey cores and chips. (See ref. 1 for a discussion of our use of Marinelli beakers.) Counting times in the icici iv. liquid samples were also necessarily short, and no radioactivity above background was detectert. although several samples counted later for one week under laboratory conditions did show very !ow concentrations of several radionuclides. These results are reported in Appendix B-2.

Beforc valid samples could be collected from the well, we needed to know that they were representa. tive of the water at depth, uncontaminated by drilling water. Bromide ion was maintained at a concentration of $30-60 \mathrm{ppm}$ in the drilling fluid to indicale its presence, but the detergent added as a drilling aid at a concentration of about $5500 \mathrm{ppm}$ pro\%ed to be a more sensitive indicator. Bromide and detcrgent concentrations were measured in the field both by LANI. and LLNL personnel using a LANL-supplied ion chromatogaph. Detergent concentrations measured during the bailing and punping sequences are listed in Appe:adix B.3.

\section{Introduction to the Log}

The sample collection log was designed to keep track of the many samples collected during the drilling, bailing, and initial pumping activities conducted at UE2On-1.

The first four characters of the sample number were derived by combining the first two letters of the site name (Cheshire) and two characters from the well name (UE20n-11) to indicate samples collected from the first satellite well at the Cheshire site. The remainder of the number is merely a sequential number; sub-sample aliquots are identified alphabetically.

Tritium was measured on most of the samples and results are not listed separately in this log. A summary of the tritium data is included in Section 2, and results of individual determinations are included in Appendix B-3. The analysis key indicates other analyses performed on each sample or aliquot. A list of the abbreviations and corresponding analyses is given below:

$$
\begin{array}{ll}
\text { C.A. } & \text { LLNL 1-I Marinelli beaker gamma count } \\
\text { IC } & \text { Anion concentrations measured by ion chromatography } \\
\text { ICP } & \text { Cation concentrations measured by inductively-coupled-plasma emission spectroscopy } \\
\text { I-129 } & \text { To be analyzed for l-129 by accelerator mass spectrometry } \\
\text { REECo } & \text { Submitted for tritium and gamma spectrometric analyses by REECo Environmental } \\
\text { Tonitoring Laboratory, Mercury } & \begin{array}{l}
\text { Analyzed for }{ }^{99} \mathrm{TC}
\end{array}
\end{array}
$$

The Volume column indicates the sample volume used for analysis, not necessarily the total volume collected. The Agency column lists the original sample-collection laboratory. For example, DRI collected samples for ficld measurements of $\mathrm{pH}$, temperature, and conductivity. Most of these samples were later released to LLNL for further analysis. All the samples listed here were analyzed in the field or 
latoratory, or placed in archives. Field and laboratory analytical results are presented in the accompanying tables. The sample description gives information concerning activitics occurring during, or immediately preceding the sample collection period. It is necessarily short, and often contains drilling; terminology. Further information regarding activitics affecting sampling during the drilling operation can be obtained by referring to the drilling log (Appendix A).

All samples iisted here are water with the exception of CH-El-13E, which is chips. This sample was requested from the USCS core library for background studies. All chips and core samples wrre logger and saved by the USCS using their labeling conventions.

Table B-1. Cheshire satellite sample log (UE20n-1).

\begin{tabular}{|c|c|c|c|c|c|c|c|}
\hline $\log N o$. & Date & $\begin{array}{l}\text { Time } \\
\text { (hiss) }\end{array}$ & $\begin{array}{c}\text { Depih } \\
\text { (ft) }\end{array}$ & $\begin{array}{c}\text { Analysis } \\
\text { key }\end{array}$ & $\begin{array}{c}\text { Volume } \\
\text { (I) }\end{array}$ & Agency & Description \\
\hline CH-E1-000 & $05 / 20 / 87$ & 0900 & $840-850$ & & 0.1 & LLNL. & Wash of the Blaoie line \\
\hline CH-E1-001 & $05 / 20 / 87$ & 1700 & 985 & & 0.1 & LLNL & Wash of the Blooie line \\
\hline CH-E1-001A & $05 / 20 / 87$ & 1700 & 985 & IC,ICP & 2.0 & LLNL & Wash of the Blooie line \\
\hline CH-E1-002 & $05 / 21 / 87$ & 1200 & 1232 & & 0.1 & LLNL. & End of the Blooie line \\
\hline CH-E1-003 & $05 / 21 / 87$ & 2140 & 1360 & C.A. & 1.0 & LLNL & End of the Blooie line \\
\hline CH-E1-004 & $05 / 22 / 87$ & 0950 & $?$ & & 11.1 & LLYL & End of the Blooie line \\
\hline No Log & $05 / 23 / 87$ & 0304 & 2080 & & 0.1 & LLNL & End of the Blooie line \\
\hline CH-EI-005 & $05 / 23 / 87$ & 0530 & 2080 & & 0.1 & LLNL. & End of the Blooie line \\
\hline CH-E1-006 & $05 / 23 / 87$ & 0700 & 2201 & & 0.1 & LLNL & End of the Blooie line \\
\hline $\mathrm{CH}-\mathrm{E} 1-007$ & $05 / 23 / 87$ & 0900 & 2320 & & 0.1 & LLNL & Bailed during logging \\
\hline CH-E1-008 & $05 / 23 / 87$ & 0930 & 2323 & C.A. & 1.0 & LLNL & First of firsl stage blowdown \\
\hline CH-E1-009 & $05 / 23 / 87$ & 0930 & 2323 & & 3.0 & LLNL & Second of first stuge blowdown \\
\hline CH-E1-009A & $05 / 23 / 87$ & 0930 & 2323 & & 1.0 & LLNL & Second of tirst stage blowdown \\
\hline CH-E1-009B & $05 / 23 / 87$ & 0930 & 2323 & REECo & 1.0 & LLNL & Second of first stoge blowdown \\
\hline CH-E1-010 & $05 / 23 / 87$ & 0930 & 2323 & & 4.0 & LINL & Third (iast) of first stage blowdown \\
\hline CH-E1-011 & $05 / 23 / 87$ & 0930 & 2323 & & 200 & L.INL & Mud pil after lirst water zone \\
\hline CH-E1-012 & $05 / 24 / 87$ & 0500 & 2323 & & 0.1 & LLNL & Bailed during logging \\
\hline CH-E 1-013 & $05 / 24 / 87$ & 1820 & 2407 & & 200 & LLNL & Blowdown-precoring \\
\hline CH-E1.013A & $05 / 24 / 87$ & 1820 & 2407 & IC & 0.5 & DI:1 & Blowdown-precoring \\
\hline $\mathrm{CH}-\mathrm{E} 1-013 \mathrm{~B}$ & $05 / 24 / 87$ & 1820 & 2407 & ICP & 0.5 & DRI & Blowdown-precoring \\
\hline CH-E1-013C & $05 / 24 / 87$ & 1820 & 2407 & REECo & 0.25 & LLNL & Blowdown-precoring \\
\hline CH-E1-013D & $05 / 24 / 87$ & 1820 & 2407 & REECo & 1.0 & LLNL & Blowdown-precoring \\
\hline CH-E1-013E & $05 / 2487$ & 1820 & 2407 & & 0.5 & LLNL & Blowdown-precoring \\
\hline CH-E1-014 & $05 / 27 / 87$ & 1100 & 2408 & C.A.TTC & 1.0 & LLNL & Lasl drillstring-precoring \\
\hline $\mathrm{CH}-\mathrm{E} 1-015$ & $05 / 27 / 87$ & 1150 & 2410 & Ic & 0.1 & LLNL & Lasl drillstring-precoring \\
\hline CH-E1-015A & $05 / 27 / 87$ & 1150 & 2410 & & 2.0 & LLNL & Last drillstring-precoring \\
\hline CH-E1-015B & $05 / 27 / 87$ & 1150 & 2410 & & 0.25 & LLNL & Last drillstring-precoring \\
\hline CH-E1-015C & $05 / 27 / 87$ & 1150 & 2410 & & 1.0 & LLNL & Last drillstring precoring \\
\hline CH-E1-016 & $05 / 27 / 87$ & 1800 & 2408 & C.A. & 4.0 & LLNL. & Serond blowdown before coring \\
\hline CH-E1-017 & $05 / 28 / 87$ & 1600 & 2423 & & 200. & LLNL & Blowdown after coring \\
\hline CH-E1-018 & $05 / 28 / 87$ & 1640 & 2423 & C.A. & 8.0 & LLNL & Last fraction after coring \\
\hline CH-E1-019 & $05 / 29 / 87$ & 0415 & 2629 & & 1.0 & LLNL & Pre-coring blowdown \\
\hline CH-E1-020 & $05 / 29 / 87$ & 0430 & 2629 & & 200. & LLNL & Blowdown before second coring \\
\hline $\mathrm{CH}-\mathrm{E} 1-020 \mathrm{~A}$ & $05 / 29 / 87$ & 0430 & 2629 & & 4.0 & LLNL. & Blowdown before second coring \\
\hline CH-E1-021 & $05 / 29 / 87$ & 0550 & 2629 & & 1.0 & LLNL & Unlabeled sample \\
\hline CH-E1-022 & $05 / 29 / 87$ & 0600 & 2629 & & 1.0 & LLNL & Unlabeled sample \\
\hline
\end{tabular}


Table B-1 (continued).

\begin{tabular}{|c|c|c|c|c|c|c|c|}
\hline Log No. & Dale & $\begin{array}{l}\text { Time } \\
\text { (hrs) }\end{array}$ & $\begin{array}{c}\text { Depth } \\
\text { (ft) }\end{array}$ & $\begin{array}{c}\text { Analysis } \\
\text { key }\end{array}$ & $\begin{array}{c}\text { Volume } \\
\text { (I) }\end{array}$ & Agency & Description \\
\hline CH-E1-023 & $05 / 29 / 87$ & 0600 & 2630 & IC & 0.5 & DRI & Pre-coring blastúlown \\
\hline CH-E1-023A & $05 / 29 / 87$ & 0600 & 2630 & ICP & 0.5 & DRI & Pre-coring blowdown \\
\hline CH-E1-024 & $05 / 29 / 87$ & 1410 & 2659 & IC & 0.5 & DRI & Firs somple afler drill resume \\
\hline CH-E1-024A & $05 / 29 / 87$ & 1410 & 2659 & $\mathbf{I C P}$ & 0.5 & DRI & Firsl sample afler drill resume \\
\hline CH-E1-025 & $05 / 30 / 87$ & 1200 & 3003 & C.A. & 1.0 & LLNL & Lal fraction before coring \\
\hline CH-E1-026 & $05 / 30 / 87$ & 1230 & 3005 & IC & 0.5 & DRJ & Last fraction before coring \\
\hline $\mathrm{CH}-\mathrm{E} 1-026 \mathrm{~A}$ & $05 / 30 / 87$ & 1230 & 3003 & ICP & 0.5 & DRI & Last fraction before coring \\
\hline CH-E1-026B & $05 / 30 / 87$ & 1230 & 3003 & & 200. & LLNL & Last fraction before coring \\
\hline $\mathrm{CH}-\mathrm{E} 1-027$ & $05 / 31 / 87$ & 0930 & 3003 & & 1.0 & LLNL & Blowdown posi core \\
\hline CH-E1-027A & $05 / 31 / 87$ & 0930 & 3003 & & 4.0 & LLNL & Blowdown posl core \\
\hline CH-E1-028 & $05 / 31 / 87$ & 1700 & 3016 & & 200 & LLNL & Blowout after coring \\
\hline CH-E1-029 & $05 / 31 / 87$ & 2300 & 3294 & IC & 0.5 & DRI & Drilling resumed \\
\hline CH-E1-029A & $05 / 31 / 87$ & 2300 & 3294 & ICP & 0.5 & DRI & Drilling resumed \\
\hline CH-E1-030 & $05 / 31 / 87$ & 2315 & 3306 & & 200. & LINL & Blowout after drilling to T.D. \\
\hline CH-E1-031 & $05 / 31 / 87$ & 2335 & 3300 & & 1.0 & LLNL & After Gyro log \\
\hline CH-E1-032 & $06 / 02 / 87$ & 1300 & 2400 & & 1.0 & USGS & Bailed by USGS \\
\hline CH-E1-033 & $06 / 02 / 87$ & 1410 & 2650 & & 1.0 & USGS & Bailed by USGS \\
\hline CH-E1-034 & $06 / 02 / 87$ & 1515 & 3000 & & 1.0 & UsGs & Bailed by USGS \\
\hline CH-E1-035 & $06 / 02 / 87$ & 1630 & 3250 & IC, ICP & 1.0 & USGS & Bailed by USGS \\
\hline CH-E1-036 & $06 / 05 / 87$ & $?$ & 2400 & & 1.0 & DRI & Bailed by DRI \\
\hline CH-E1-037 & $06 / 05 / 87$ & 1600 & 2650 & & 1.0 & DRI & Bailed by DRI \\
\hline CH-E1-038 & $06 / 05 / 87$ & 1700 & 3000 & & 1.0 & DRI & Bailed by DRI \\
\hline CH-E1-038A & $06 / 05 / 87$ & 1700 & 3000 & & 1.0 & DRI & Bailed by DRI \\
\hline CH-E1-039 & $06 / 05 / 87$ & 2040 & 3286 & & 1.0 & DRI & Bailed by DRI \\
\hline CH-E1-039A & $06 / 05 / 87$ & 2040 & 3286 & & 1.0 & DRI & Bailed by DRI \\
\hline CH-E1-040 & $06 / 08 / 87$ & 1430 & 2400 & IC,ICP & 1.0 & DRI & Bailed by DRI \\
\hline CH-E1-040A & $06 / 08 / 87$ & 1430 & 2400 & & 1.0 & DRI & Bailed by DRI \\
\hline CH-E1-041 & $06 / 08 / 87$ & 1530 & 2650 & IC,ICP,C.A. & 1.0 & DRI & Bailed by DRI \\
\hline CH-E1-041A & $06 / 08 / 87$ & 1530 & 2650 & & 1.0 & DRI & Bailed by DRI \\
\hline CH-E1-042 & $06 / 08 / 87$ & 1659 & 3000 & IC,ICP & 1.0 & DRI & Bailed by DRI \\
\hline $\mathrm{CH}-\mathrm{E} 1-042 \mathrm{~A}$ & $06 / 08 / 87$ & 1659 & 3000 & & 1.0 & DRI & Bailed by DRI \\
\hline CH-E1-043 & $06 / 08 / 87$ & $?$ & 3250 & IC,ICP & 1.0 & DRI & Bailed by DRI \\
\hline $\mathrm{CH}-\mathrm{E} 1-043 \mathrm{~A}$ & $06 / 08 / 87$ & $?$ & 3250 & & 1.0 & DRI & Bailed by DRI \\
\hline $\mathrm{CH}-\mathrm{E} 1-044$ & $06 / 22 / 87$ & 1315 & 2850 & & 1.0 & DRI & Pumped by DRI \\
\hline CH-E1-045 & $06 / 22 / 87$ & 1345 & 2850 & & 1.0 & DRI & Pumped by DRI \\
\hline CH-E1-046 & $06 / 22 / 87$ & 1400 & 2850 & & 1.0 & DRI & Pumped by DRI \\
\hline CH-EI.047 & $06 / 22 / 87$ & 1500 & 2850 & & 1.0 & DRI & Pumped by DRI \\
\hline CH-E1-048 & $06 / 22 / 87$ & 1600 & 2850 & & 1.0 & DRI & Pumped by DRI \\
\hline CH-E1-049 & $06 / 22 / 87$ & 1700 & 2850 & & 1.0 & DRI & Punped by DRI \\
\hline CH-E1-050 & $06 / 22 / 87$ & 1800 & 2850 & & 1.0 & DRI & Pumped by DRI \\
\hline CH-E1-051 & $06 / 22 / 87$ & 1900 & 2850 & & 1.0 & DRI & Pumped by DRI \\
\hline CH-E1-052 & $06 / 22 / 87$ & 2100 & 2850 & & 1.0 & DRI & Pumped by DRI \\
\hline CH-E1-053 & $06 / 22 / 87$ & 2200 & 2850 & & 1.0 & DRI & Pumped by DRI \\
\hline CH-E1-054 & $06 / 23 / 87$ & 0000 & 2850 & & 1.0 & DRI & Pumped by DRI \\
\hline CH-E1-055 & $06 / 23 / 87$ & $n: 00$ & 2850 & & 1.0 & DRI & Pumped by DRI \\
\hline CH-E1-056 & $06 / 23 / 87$ & 0400 & 2850 & & 1.0 & DRI & Pumped by DRI \\
\hline CH-E1-057 & $06 / 23 / 87$ & 0600 & 2850 & & 1.0 & DRI & Pumped by DRI \\
\hline CH-E1-058 & $06 / 23 / 87$ & 0900 & 2850 & IC,ICP & 1.0 & LLNL & Collected at the end af $20 \mathrm{hrs}$ \\
\hline CH-E1-059 & $07 / 07 i 87$ & 1200 & 2850 & & 1.0 & LLNL & $\begin{array}{l}\text { Starled pump at } 1055 \text { water level } \\
2033 \text { ft }\end{array}$ \\
\hline
\end{tabular}


Table B-1 (continued).

\begin{tabular}{|c|c|c|c|c|c|c|c|}
\hline $\log N o$. & Date & $\begin{array}{l}\text { Time } \\
\text { (hrs) }\end{array}$ & $\begin{array}{c}\text { Depth } \\
\text { (ft) }\end{array}$ & $\begin{array}{c}\text { Analysis } \\
\text { key }\end{array}$ & $\begin{array}{c}\text { Volume } \\
\text { (l) }\end{array}$ & Agency & Description \\
\hline CH-E1-059A & $07 / 07 / 87$ & 1200 & 2850 & & 0.250 & DRI & $\begin{array}{l}\text { Started pump = } 1055 \text { water level } \\
2033 \text { it }\end{array}$ \\
\hline CH-E1-060 & $07 / 07 / 87$ & 1300 & 2850 & & 1.0 & LLNL & LLNL sumpling/monitoring \\
\hline CH-E1-060A & $07 / 07 / 87$ & 1300 & 2850 & IC,ICP & 250 & DRI & LINL sumpling/manitoring \\
\hline CH-E1-061 & $07 / 07 / 87$ & 1400 & 2850 & & 1.0 & LLNL & LLNL sampling/monitoring \\
\hline CH-E1-061A & $07 / 07 / 87$ & 1400 & 2850 & IC & 250 & DRI & LLNL sampling/monitoring \\
\hline CH-E1-062 & $07 / 07 / 87$ & 1500 & 2850 & & 1.0 & LLVL & LLNL sumpling/monitoring \\
\hline CH-E1-062A & $07 / 07 / 87$ & 1500 & 2850 & & 250 & DRI & LLNL sampling/monitoring \\
\hline CH-E1-063 & $07 / 07 / 87$ & 1600 & 2850 & & 1.0 & LLNL & Pumped sample \\
\hline CH-E1-063A & $07 / 07 / 87$ & 1600 & 2850 & & .250 & DRI & Pumped sample \\
\hline CH-E1-064 & $07 / 07 / 87$ & 1700 & 2850 & Te & 1.0 & LENL & Pumped sample \\
\hline CH-E1-064A & $07 / 07 / 87$ & 1700 & 2850 & & 250 & DRI & Pumped sample \\
\hline CH-E1-065 & $07 / 07 / 87$ & 1800 & 2850 & Te & 1.0 & LLNL & Pumped sample \\
\hline$C H-E 1-065 A$ & $07 / 07 / 87$ & 1800 & 2850 & & .250 & DRI & Pumped sumple \\
\hline CH-E1-066 & $07 / 07 / 87$ & 2100 & 2850 & & 1.0 & LLNL & Pumped sample \\
\hline CH-E1-066f: & $07 / 07 / 87$ & 2100 & 2850 & IC,ICP & 250 & DRI & Pumped sumple \\
\hline CH-E1-wh7 & $07 / 08 / 87$ & 0645 & 2850 & & 1.0 & LLAL & Pumped sample \\
\hline CH-E1-068 & $07 / 08 / 87$ & 0800 & 2850 & & 1.0 & LLNL & Pumped sample \\
\hline $\mathrm{CH}-\mathrm{E} 1-068 \mathrm{~A}$ & $07 / 08 / 87$ & 0800 & 2850 & & .250 & DRI & Pumped sample \\
\hline CH-E1-069 & $07 / 08 / 87$ & 0900 & 2850 & & 1.0 & LLVL & Pumped sample \\
\hline CH-E1-070 & $07 / 08 / 87$ & 1000 & 2850 & & 1.0 & LLNL & Pumped sample \\
\hline $\mathrm{CH} \cdot \mathrm{E1}-071$ & $07 / 08 / 87$ & 1100 & 2850 & & 1.0 & LLNL & Pumped sample \\
\hline $\mathrm{CH}-\mathrm{E} 1-072$ & $07 / 08 / 87$ & 1300 & 2850 & & 1.0 & LLNL & Pumped sarnple \\
\hline $\mathrm{CH}-\mathrm{E} 1-073$ & $07 / 08 / 87$ & 1400 & 2850 & & 1.0 & LLVL & Pumped sample \\
\hline $\mathrm{CH}-\mathrm{E} 1-074$ & $07 / 08 / 87$ & 1500 & 2850 & & 1.0 & LLNL & Pumped sample \\
\hline CH-E1-075 & $07 / 08 / 87$ & 1600 & 2850 & & 1.0 & I LNL & Pumped sample \\
\hline $\mathrm{CH}-\mathrm{E} 1-076$ & $07 / 08 / 87$ & 1700 & 2850 & & 1.0 & LLNL & Pumped sample \\
\hline CH-E1-077 & $07 / 08 / 87$ & 1900 & 2850 & IC,ICP & 1.0 & LLNI & Pumped sample \\
\hline CH-E1-077A & $07 / 08 / 87$ & 1900 & 2850 & IC,ICP & 250 & LLNL & Pumped somple \\
\hline $\mathrm{CH}-\mathrm{E} 1-078$ & $07 / 09 / 87$ & 0645 & 2850 & & 1.0 & LLNL & Pumped sample \\
\hline CH-E1-079 & $07 / 09 / 87$ & 0800 & 2850 & & 1.0 & LLNL & Pumped sample \\
\hline CH-E1-079A & $07 / 09 / 87$ & 3900 & 2850 & & 1.0 & LLNL & Pump off al 1225 \\
\hline CH-E1-079B & $07 / 09 / 87$ & 1000 & 2850 & IC,ICP & 1.0 & LLNL & Pumped sample \\
\hline $\mathrm{CH}-\mathrm{E} 1.079 \mathrm{C}$ & $07 / 99 / 87$ & 1100 & 3850 & & 1.0 & LLNL & Pumped sample \\
\hline $\mathrm{CH}-\mathrm{E} 1-079 \mathrm{D}$ & $07 / 09 / 87$ & 1100 & $28: 0$ & Te & 200. & LLNL & Pumped sample \\
\hline CH-E1-079E & $07 / 09 / 87$ & 1100 & 2850 & Te & 200. & LLNL & Pumped sample \\
\hline $\mathrm{CH}-\mathrm{E} 1-080$ & $07 / 20 / 87$ & - & 2400 & & 1.0 & LLNL & DRI bailed samples \\
\hline $\mathrm{CH}-\mathrm{E} 1-080 \mathrm{~A}$ & $07 / 20 / 87$ & - & 2400 & ICP & .250 & LLNL & DRI bailed samples \\
\hline $\mathrm{CH}-\mathrm{E} 1-081$ & $07 / 20 / 87$ & - & 2600 & C.A. & 1.0 & LLNL & DRI bailed samples \\
\hline CH-E1-081A & $07 / 20 / 87$ & - & 2600 & ICP & .250 & LLNL & DRI bailed sam les \\
\hline CH-E1-082 & $07 / 20 / 87$ & - & 2750 & Te & 1.0 & LLNL & DRI bailed sum iles \\
\hline CH-E1-082A & $07 / 20 / 87$ & - & 2750 & & .250 & LLNL & DRI bailed samples \\
\hline $\mathrm{CH}-\mathrm{E} 1-083$ & $07 / 20 / 87$ & 1300 & 2750 & C.A. & 1.0 & LLNL & LLNL sampling/monitoring \\
\hline CH-E1-084 & $07 / 20 / 87$ & 1400 & 2750 & & 1.0 & LLNL & LLNL sampling/monitoring \\
\hline CH-E1-085 & $07 / 20 / 87$ & 1500 & 2750 & & 1.0 & LLNL & LLNL sampling/monitoring \\
\hline CH-E1-086 & $07 / 20 / 87$ & 1600 & 2750 & Tc & 1.0 & LLNL & LLNL sampling/monitoring \\
\hline CH-E1-087 & $07 / 20 / 87$ & 1700 & 2750 & & 1.0 & LLNL & LLNL sampling/monitoring \\
\hline CH-E1-088 & $07 / 20 / 87$ & 1800 & 2750 & & 1.0 & LLNL & LLNL sampling/monitoring \\
\hline CH-E1-089 & $07 / 22 / 87$ & 1000 & 2750 & IC,ICP & 1.0 & LLNL & LLNL sampling/monitoring \\
\hline CH-E1-090 & $07 / 22 / 87$ & 1100 & 2750 & & 1.0 & LLNL & LLNL sampling/monitoring \\
\hline
\end{tabular}


Table B-1 (continued).

\begin{tabular}{|c|c|c|c|c|c|c|c|}
\hline Log No. & Date & $\begin{array}{l}\text { Time } \\
\text { (hrs) }\end{array}$ & $\begin{array}{c}\text { Depth } \\
\text { (ft) }\end{array}$ & $\begin{array}{c}\text { Analysis } \\
\text { key }\end{array}$ & $\begin{array}{c}\text { Volume } \\
\text { (I) }\end{array}$ & Agency & Description \\
\hline CH-E1-091 & $07 / 22 / 87$ & 1200 & 2750 & & 1.0 & LLNL & LLNL sampling/monitoring \\
\hline CH-E1-092 & $07 / 22 / 87$ & 1300 & 2750 & & 1.0 & LLSL & LLNL sampling/monitoring \\
\hline CH-E1-093 & $07 / 22 / 87$ & 1400 & 2750 & & 1.0 & LLNL & LLNL sampling/monitoring \\
\hline CH-E1-094 & $07 / 22 / 87$ & 1500 & 2750 & Tc & 1.0 & LLNL & LLNL sampling/monitoring \\
\hline CH-E1-095 & $07 / 22 / 87$ & 1600 & 2750 & IC,ICP & 1.0 & LLNL & LINL sampling/monitoring \\
\hline CH-E1-095A & $07 / 22 / 87$ & 1600 & 2750 & IC,ICP & 250 & LLNL & LLNL sampling/monitoring \\
\hline CH-E1-096 & $07 / 23 / 87$ & 0950 & 2750 & CAATe & 1.0 & LLNL & Planned continuous pumping \\
\hline CH-E1-096A & $07 / 23 / 87$ & 0950 & 2750 & & 200 & LLNL & Planned continuous pumping \\
\hline CH-E1-097 & $07 / 23 / 87$ & 1015 & 2750 & & 200 & LLNL & Planned continuous pumping \\
\hline CH1-E1-098 & $07 / 23 / 87$ & $?$ & 2400 & $1-129$ & 1.0 & DRI & Bailed by DRI \\
\hline CH-E1-098A & $07 /<2,37$ & $?$ & 2400 & & 0.25 & DRI & Bailed by DRI \\
\hline CH-E1-099 & $03 / 23 / 87$ & $?$ & 2600 & Te & 1.00 & DRI & Bailed by DRI \\
\hline CH-E1-099 A & $07 / 23 / 87$ & $?$ & 2600 & IC,ICP & 0.25 & DRI & Bailed by DRI \\
\hline CH-E1-100 & $08 / 06 / 87$ & 1600 & 2750 & Tc & 0.25 & DRI & Pump failed and was rebuilt \\
\hline CH-E1-101 & $08 / 06 / 87$ & 1700 & 2750 & & 1.00 & DRI & Collected by DRI Huchens \\
\hline CHI-E1-102 & $08 / 06 / 87$ & 1800 & 2750 & IC,ICP & 1.00 & DRI & Collecied by DRI Huckens \\
\hline CH-E1-103 & $08 / 06 / 87$ & 1830 & 2750 & & 1.00 & DRI & Collecied by DRI Huckens \\
\hline CH-E1-104 & $08 / 06 / 87$ & 1930 & 2750 & IC,ICP,CA. & 1.00 & DRI & Collexied by DRI Huckens \\
\hline
\end{tabular}

Analysis key: C.A.-Counting aliquot

REECo - LLNL results confirmed by REECo Environmental Monitoring Laboratory

Tc-Aliquol for ${ }^{99} \mathrm{Tc}$

IC - Anions measured by ion chromatograph

ICP - Cations measured by inductively-coupied-plasma emission spectroscopy

I-129 - Measurement by acceleralor mass spectrometry 
Appendix B-2. $\psi$-Ray-Emilting Radionuclides in 1987 Samples of Water from UE20n1 (Detonation Time, 2/14/76).

Table B-2. Concentrations of gamma-emitting radionuclides in unfiltered water from UE20n-1, as determined by counting in Marinelli beakers, corrected to detonation time, $\mu \mathrm{Ci} / \mathrm{ml}$

\begin{tabular}{|c|c|c|c|c|c|c|c|c|c|c|}
\hline $\begin{array}{l}\text { Dale } \\
\text { Depth (ft) } \\
\text { Volume (1) } \\
\text { iog No. }\end{array}$ & $\begin{array}{c}5 / 21 / 87 \\
1360 \\
0.8621 \\
\text { CH-E1-3 }\end{array}$ & $\begin{array}{c}5 / 23 / 87 \\
2323 \\
0.9838 \\
\text { CH-E1-8 }\end{array}$ & $\begin{array}{c}5 / 27 / 87 \\
2408 \\
0.9464 \\
\text { CH-E1-14 }\end{array}$ & $\begin{array}{c}5 / 2887 \\
2423 \\
0.9512 \\
\text { CH-E1-18 }\end{array}$ & $\begin{array}{c}530187 \\
3003 \\
0.9725 \\
\text { CHI-E]-25 }\end{array}$ & $\begin{array}{c}\text { 68187 } \\
2650^{\circ} \\
0.9473 \\
\text { CH-E1-41 }\end{array}$ & $\begin{array}{c}720 \times 87 \\
26004 \\
0.970 ? \\
\text { CH-EI-81 }\end{array}$ & $\begin{array}{c}720157 \\
2750^{\circ} \\
0.9001 \\
\text { CH-E1-B3 }\end{array}$ & $\begin{array}{c}723 \times 87 \\
2750^{\circ} \\
0.9797 \\
\text { CH-E1-96 }\end{array}$ & $\begin{array}{c}\text { abrs: } \\
2759^{b} \\
0.9583 \\
\text { CH-E1-104 }\end{array}$ \\
\hline \multicolumn{11}{|l|}{ Nuclide } \\
\hline${ }^{22} \mathrm{Na}$ & $<1 E-08$ & $<1 E-08$ & $<1 E-08$ & 2.31E- 08 & $<1 E-00$ & $1.08 E-08$ & C1E-08 & $<1 E-\infty$ & CIE-OB & i.18L-0.s \\
\hline $125 \mathrm{sb}$ & $<1 E-08$ & $1.33 \mathrm{E}-07$ & $227 \mathrm{E}-06$ & $1.79 E-06$ & $246 E-03$ & $8.41 E-07$ & ISAEAS & $10 \pi t-06$ & $1.03 E-06$ & $9.07 E-07$ \\
\hline${ }^{337} \mathrm{Cs}$ & $<1 E-09$ & $<1 E-09$ & $<1 E-0 ;$ & $<] E-09$ & $<1 E-0$ ) & $<1 E-\infty$ & 3.17:-09 & $<1 E-09$ & CIE-OS & $<I E-09$ \\
\hline
\end{tabular}

a. Bailed

b. Pumped

Several other long-lived radionuclides might be present in the water from UE20n-1.

Lipper limits for their detection in a 1-liter sample are given below $(\mu \mathrm{Ci} / \mathrm{ml})$ :

$\begin{array}{llll}{ }^{54} \mathrm{Mn} & 1 \mathrm{E}-09 & { }^{144} \mathrm{Ce} & 2 \mathrm{E}-09 \\ { }^{60} \mathrm{Co} & 1 \mathrm{E}-09 & { }^{352} \mathrm{Eu} & 3 \mathrm{E}-09 \\ { }^{85} \mathrm{Kr} \cdot & 1 \mathrm{E}-09 & { }^{154} \mathrm{Eu}: & 2 \mathrm{E}-09 \\ { }^{106} \mathrm{Ru} & 2 \mathrm{E}-09 & { }^{155} \mathrm{Eu}: & 3 \mathrm{E}-09\end{array}$


Table A-1 (continued).

\begin{tabular}{llllllc}
\hline Event name & Hole name & Sponsor & Date & DOB, $m$ & SWL, $m$ & SWLql \\
\hline Dalhart & U4U & LANL & $\mathbf{1 0 / 1 3 / 8 8}$ & 640.100 & 508 & est. \\
Texarkana & U7CA & LANL & $02 / 10 / 89$ & $\mathbf{5 0 2 . 9 0 0}$ & 519 & meas. \\
Amarillo & U19AY & LANL & $\mathbf{0 6 / 2 7 / 8 9}$ & $\mathbf{6 4 0 . 1 0 0}$ & 649 & meas. \\
Homitos & U2QBC & LLNL & $10 / 31 / 89$ & 563.900 & 569 & meas. \\
\hline
\end{tabular}

* Erratum. The 1987 report incorrectly gives the units as feet, instead of meters. 
Table B-3. Part 3: Pumping sequence.

\begin{tabular}{|c|c|c|c|c|c|c|c|c|c|}
\hline $\begin{array}{l}\text { Sample } \\
\text { Log No. }\end{array}$ & Date & Time & $\begin{array}{c}\text { Total } \\
\text { volume } \\
\text { pumped } \\
\text { (gal) }\end{array}$ & $\begin{array}{c}\text { DRI" } \\
\text { temp } \\
\text { (deg C }\end{array}$ & $\begin{array}{c}\text { DRI* } \\
\text { pH }\end{array}$ & $\begin{array}{l}\text { DRI" } \\
\text { E_C. }\end{array}$ & $\begin{array}{c}\text { LLVL } \\
\text { detergent } \\
\text { (ppin) }\end{array}$ & 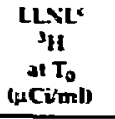 & $\begin{array}{c}\text { LISLE } \\
\text { JH } \\
\text { S.D. } \\
\text { (F, emos) }\end{array}$ \\
\hline- & $06 / 22 / 87$ & 1307 & - & & & & & & \\
\hline CH-El-0.46 & $06 / 22 / 87$ & 1400 & 742 & - & - & - & - & 4.19E-01 & (1) \\
\hline CH-E 1-047 & $06 / 22 / 87$ & 1500 & 1582 & - & - & - & - & 4.54E-0\} & (1) \\
\hline CH-E1-048 & $06 / 22 / 87$ & 1600 & 2422 & - & - & - & - & 4.39E-01 & (1) \\
\hline CH-E1-049 & $06 / 22 / 87$ & 1700 & 3262 & - & - & - & - & 4. 7 E-01 & (1) \\
\hline CH-E1-050 & $06 / 22 / 87$ & 1800 & +102 & - & - & - & - & $4.76 \mathrm{E}-01$ & (I) \\
\hline $\mathrm{CH}-\mathrm{E} 1-051$ & $06 / 22 / 87$ & 1900 & 4942 & - & - & - & - & $4.86 E-01$ & 0.51 \\
\hline $\mathrm{CH} \cdot \mathrm{E} 1.052$ & $06 / 22 / 87$ & 2106 & 6622 & - & - & - & - & 6.13E-01 & (1) \\
\hline CH-E1-053 & $06 / 22 / 87$ & 2200 & 7162 & - & - & - & - & 4.+8E-01 & (1) \\
\hline $\mathrm{CH}-\mathrm{E} 1.054$ & $06 / 23 / 87$ & 0000 & 9142 & - & - & - & 一 & $5.07 E-01$ & 2.52 \\
\hline CH-E1-055 & $06 / 23 / 87$ & 0200 & 10822 & - & - & - & - & S.00E.01 & 2.82 \\
\hline $\mathrm{CH}-\mathrm{E} 1-056$ & $06 / 23 / 87$ & 0400 & 12502 & - & - & - & - & $5.14 E-01$ & (1) \\
\hline CH-E 1-057 & $06 / 23 / 87$ & 0600 & 14182 & - & - & - & - & $4.99 E-01$ & 1.48 \\
\hline CH-E1-058 & $06 / 23 / 87$ & 0900 & 16702 & - & - & - & - & S.00E-01 & 2.30 \\
\hline - & $07 / 07 / 87$ & 1055 & 17052 & & & & & & \\
\hline CHI-E1-059 & $07 / 07 / 87$ & 1200 & 17962 & 28 & 8.08 & 445 & - & $+83 \mathrm{E}-01$ & 0.98 \\
\hline CH-E1-060 & $07 / 07 / 87$ & 1300 & 18802 & 30 & 7.96 & 429 & - & 5.8.AE-01 & 3.17 \\
\hline CHI-E 1-061 & $07 / 07 / 87$ & 1400 & $196+2$ & 31 & 7.72 & 387 & 16 & $5.94 \mathrm{E}-01$ & 2.70 \\
\hline CH-E $1-0.62$ & $07 / 07 / 87$ & 1500 & 20482 & 33 & 7.74 & 390 & - & $5.88 \mathrm{E}-01$ & 1.14 \\
\hline $\mathrm{CH}-\mathrm{E} 1-0 \mathrm{OS} 3$ & $07 / 07 / 87$ & 1600 & $21\} 22$ & 33 & 7.74 & 404 & - & 6.38E-01 & 1.78 \\
\hline CH-E 1-06- & $07 / 07 / 87$ & 1700 & 22162 & 33 & - & - & - & 6.35E-01 & 1.00 \\
\hline CH-EI-065 & $07 / 07 / 87$ & 1800 & 23002 & 31 & - & - & 15 & 6.01E-01 & 5.13 \\
\hline CH-E -1066 & $07 / 07 / 87$ & 2130 & 25522 & 33 & - & - & - & 6.10E-01 & 1.69 \\
\hline $\mathrm{CH}-\mathrm{E} 1.067$ & $07 / 08 / 87$ & 0645 & 33712 & 33 & 7.78 & 345 & 15 & $5.13 \mathrm{E}-01$ & 2.95 \\
\hline $\mathrm{CH}-\mathrm{E} 1-068$ & $07 / 08 / 87$ & 0800 & 34762 & 34 & 7.74 & 368 & - & $5.16 \mathrm{E}-01$ & 4.67 \\
\hline C11-E1-069 & $\lfloor 7 / 08 / 87$ & 0900 & 35602 & 33 & 7.90 & 370 & - & $5.64 \mathrm{E}-01$ & 4.65 \\
\hline CH-EI-070 & $07 / 08 / 87$ & 1000 & 36412 & 33 & 7.80 & 346 & - & $5.77 \mathrm{E}-01$ & 4.26 \\
\hline CH-E1-071 & $07 / 08 / 87$ & $: 100$ & 37282 & 33 & 7.86 & 377 & - & $5.20 \mathrm{E}-01$ & 5.14 \\
\hline CH-E1-072 & $07 / 08 / 67$ & 1300 & 38962 & 32 & 7.96 & 356 & - & 5.79E-01 & 4.93 \\
\hline CH-E1-073 & $07 / 08 / 87$ & 1400 & 39802 & 32 & 7.91 & 376 & - & $6.18 \mathrm{E}-01$ & 5.01 \\
\hline CHI-E1-074 & $07 / 08 / 87$ & 1500 & 40642 & 32 & 7.74 & 360 & - & $6.12 \mathrm{E}-01$ & 3.16 \\
\hline $\mathrm{CH}-\mathrm{E} 1-075$ & $07 / 08 / 87$ & 1600 & 41482 & 33 & 7.76 & 352 & - & $5.32 \mathrm{E}-01$ & 5.00 \\
\hline $\mathrm{CH} \cdot \mathrm{E} 1.076$ & $07 / 08 / 87$ & 1700 & 42322 & 24 & 7.72 & 348 & 16 & $5.57 \mathrm{E}-01$ & 5.08 \\
\hline CH-El-077 & $07 / 08 / 87$ & 1900 & 44002 & 32 & - & 340 & - & $6.48 E-01$ & 4.52 \\
\hline $\mathrm{CH}-\mathrm{E} 1-078$ & $0 \% / 09 / 87$ & 0645 & 53872 & 34 & 7.40 & 344 & 14 & $6.27 \mathrm{E}-01$ & 1.81 \\
\hline CH-E1-079 & $07 / 09 / 87$ & 0840 & 54922 & - & 7.65 & 353 & - & $5.76 \mathrm{E}-01$ & 1.64 \\
\hline CH-E1-079A & $07 / 09 / 87$ & 0900 & 55762 & 32 & 7.75 & 363 & - & $4.91 \mathrm{E}-01$ & 1.26 \\
\hline CH-E1-079B & $07 / 09 / 87$ & 1000 & 56502 & .23 & 7.90 & 368 & 一 & $5.41 E-0]$ & 3.66 \\
\hline CH-E1-079C & $07 / 09 / 87$ & 1100 & 57442 & 33 & 7.82 & 350 & - & 6.17E-DI & $4.4 n$ \\
\hline- & $07 / 09 / 87$ & 1225 & 58632 & Pump off & & & & & \\
\hline
\end{tabular}


Table B-3. Part 3 (conti sued).

\begin{tabular}{|c|c|c|c|c|c|c|c|c|c|}
\hline $\begin{array}{l}\text { Sample } \\
\text { Log No. }\end{array}$ & Date & Time & $\begin{array}{l}\text { Total } \\
\text { volume } \\
\text { pumped } \\
\text { (yal) }\end{array}$ & $\begin{array}{c}\text { DRE } \\
\text { temp } \\
\text { ldes } C\end{array}$ & $\begin{array}{c}\text { DRI } \\
\text { pH }\end{array}$ & $\begin{array}{l}\text { DRI } \\
\text { EC. }\end{array}$ & $\begin{array}{c}\text { U1NL } \\
\text { detirgen| } \\
\text { 'ppim| }\end{array}$ & 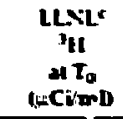 & $\begin{array}{l}\text { HLE* } \\
\text { SII } \\
\text { S.D. } \\
\text { (\% enor) }\end{array}$ \\
\hline- & $07 / 19 / 87$ & 1950 & 58632 & Pump on & & & & & \\
\hline CH-E1-083 & $07 / 20 / 87$ & 1300 & 72142 & - & - & - & 25 & (.02E-01 & 1.48 \\
\hline CH-E1-084 & $07 / 20 / 87$ & 1400 & 72992 & - & - & - & - & (2.12E-01 & 1.01 \\
\hline CH-E1-085 & $07 / 20 / 87$ & 1500 & 73822 & - & - & - & - & S.93E-01 & (II) \\
\hline CH-E1-086 & $07 / 20 / 87$ & 1600 & 74662 & - & - & - & - & 5.TSE-OL & 1.70 \\
\hline CH-E1-087 & $07 / 20 / 87$ & 1700 & 75502 & - & - & - & - & 5.SOE-OI & 0.33 \\
\hline CH-E!-088 & $07 / 20 / 87$ & 1800 & 76342 & - & $\rightarrow$ & - & - & $5.72 E-01$ & 1.32 \\
\hline- & & & & - & - & - & - & & \\
\hline CH-E1-089 & $07 / 22 / 87$ & 1000 & 85582 & - & - & - & 5.0 & S.66E-01 & 2.76 \\
\hline CH-E1-090 & $07 / 22 / 87$ & 1100 & $86+22$ & - & - & - & - & 5.71E-01 & 0.16 \\
\hline CH-E1-091 & $07 / 22 / 87$ & 1200 & 87262 & $\rightarrow$ & - & - & 一 & S.GAE-כI & 3.17 \\
\hline CH-E $1-092$ & $07 / 22 / 87$ & 1300 & 88102 & - & - & - & - & j.99E-01 & 0.90 \\
\hline CH-E1-093 & $07 / 22 / 87$ & 1400 & 88942 & - & - & - & - & S.84E-91 & 180 \\
\hline $\mathrm{CH}-\mathrm{E} 1-094$ & $07 / 22 / 87$ & 15tu & 89782 & - & - & - & - & S.78E-01 & 1.92 \\
\hline CH-E1-095 & $07 / 22 / 67$ & 1600 & 90622 & - & - & - & - & $5.73 E-01$ & 2.17 \\
\hline- & $07 / 22 / 87$ & 2200 & 95662 & - & - & - & - & & \\
\hline CH-E 1-096 & $07 / 23 / 87$ & 0950 & 103784 & - & - & - & 3.0 & S.91E-0t & 0.78 \\
\hline- & $07 / 23 / 87$ & 1545 & 103784 & - & - & - & - & & \\
\hline- & $07 / 27 / 87$ & 1045 & 178856 & - & - & - & - & & \\
\hline- & $07 / 28 / 87$ & 2257 & 208820 & 一 & 一 & - & - & & \\
\hline- & $08 / 03 / 87$ & 1441 & 208820 & - & - & - & - & & \\
\hline- & $08 / 04 / 87$ & 1800 & 259802 & - & - & - & - & & \\
\hline CH-E1-100 & $23 / 06 / 87$ & 1600 & 260223 & - & - & - & - & $5.48 E-01$ & (1) \\
\hline CH-E1-JO1 & $08 / 06 / 87$ & 1700 & 261063 & - & - & - & - & $5.56 E-01$ & (1) \\
\hline$\left.C_{1} I-E\right]-102$ & $08 / 06 / 87$ & 1800 & 261903 & - & - & - & - & $5.63 \mathrm{E}-01$ & (1) \\
\hline CHI-E1-103 & $08 / 06 / 87$ & 1830 & 262323 & - & - & - & 1.0 & 5.97E-01 & 0.63 \\
\hline CH-E1-104 & $08 / 06 / 87$ & 1930 & 253163 & - & - & - & - & $5.69 E-01$ & (1) \\
\hline
\end{tabular}

a. Temperature, $\mathrm{pH}$, and electrical conductivity $(\mu \mathrm{mhos} / \mathrm{cm}$ ) were measured by $\mathrm{DRI}$.

b. Field measurements are only approximate due to counting conditions. Results of more accurate measuremtnts made under laboratory conditions are given in Appendix B-2.

c. Samples for tritium analysis were filtered through 0.45 micron filter prior to mixing with liquid scintillation counting cocktail.

d. These two samples were also analyzed by REECo Environmental Menitoring Laboratory, who confirmed the LLNL results.

e. Numbers in parentheses are one standard deviation based on a single count. Others are calculated from two or more replicates. 
Table B-4. Laboratory-measured concentrations in UE20n-1 water of trace cations and anions, ${ }^{\mathrm{a}} \mathrm{mg} / 1$ (ppm).

\begin{tabular}{|c|c|c|c|c|c|c|c|c|c|c|c|c|c|c|c|c|c|c|c|}
\hline $\begin{array}{l}\text { Sample } \\
\log \text { no. }\end{array}$ & Date & Time & $\begin{array}{c}\text { Depth } \\
\text { (ft) }\end{array}$ & Al & K & Fe & B & Li & $\mathrm{Na}$ & $\mathbf{S i}$ & $\mathbf{M}_{\mathrm{g}}$ & $\mathrm{Ca}$ & I & CI & $\mathrm{NO}_{3}$ & $\mathrm{SO}_{4}$ & $\mathrm{ICO}_{3}$ & $\mathrm{Br}$ & $\begin{array}{l}\text { Deterg- } \\
\text { snt }\end{array}$ \\
\hline $\begin{array}{l}\text { Drilling S } \\
\text { CH-E1-1 } \\
\text { CH-E1-8 } \\
\text { CH-E1-9 } \\
\text { CH-E1-12 } \\
\text { CH-EH-13 } \\
\text { CH-E1-23 } \\
\text { CHH-E1-24 } \\
\text { CH-E1-26 } \\
\text { CHI-E1-29 }\end{array}$ & $\begin{array}{l}\text { eries } \\
05 / 20 / 87 \\
05 / 23 / 87 \\
05 / 23 / 87 \\
05 / 24 / 87 \\
05 / 24 / 87 \\
05 / 29 / 87 \\
05 / 29 / 87 \\
05 / 30 / 87 \\
05 / 31 / 87\end{array}$ & $\begin{array}{l}1700 \\
0930 \\
0930 \\
0500 \\
1820 \\
0600 \\
1410 \\
1230 \\
2300\end{array}$ & $\begin{array}{r}985 \\
2323 \\
2323 \\
232.3 \\
2407 \\
26.30 \\
2659 \\
3003 \\
3294\end{array}$ & $\begin{array}{l}0.637 \\
- \\
- \\
<0.005 \\
<0.005 \\
<0.005 \\
<0.005 \\
<0.005\end{array}$ & $\begin{array}{l}1.5 \\
= \\
= \\
= \\
=\end{array}$ & $\begin{array}{l}0.133 \\
- \\
- \\
- \\
0.294 \\
1.590 \\
0.812 \\
1.260 \\
0.456\end{array}$ & $\begin{array}{l}0.092 \\
\overline{-} \\
\overline{-} \\
0.279 \\
0.248 \\
0.200 \\
0.138 \\
0.091\end{array}$ & $\begin{array}{l}0.09 \\
- \\
- \\
- \\
0.190 \\
0.099 \\
0.483 \\
0.080 \\
0.044\end{array}$ & $\begin{array}{l}52.68 \\
= \\
= \\
- \\
85.8 \\
75.4 \\
118.4 \\
70.5 \\
65.2\end{array}$ & $\begin{array}{c}17.12 \\
- \\
- \\
- \\
36.41 \\
30.07 \\
25.64 \\
29.23 \\
26.62\end{array}$ & $\begin{array}{l}0.230 \\
- \\
- \\
- \\
0.640 \\
0.258 \\
0.246 \\
0.041 \\
0.034\end{array}$ & $\begin{array}{c}3.59 \\
- \\
- \\
- \\
39.0 \\
8.34 \\
10.1 \\
7.12 \\
7.30\end{array}$ & $\begin{array}{l}2.8 \\
\text { N.A." } \\
\text { N.A. } \\
\text { N.A. } \\
5.2 \\
4.5 \\
4.1 \\
2.4 \\
2.6\end{array}$ & $\begin{array}{l}5.4 \\
N . \Lambda . \\
N . \Lambda . \\
N . \Lambda . \\
16.7 \\
13.4 \\
20.4 \\
11.4 \\
10.7\end{array}$ & $\begin{array}{l}2.9 \\
\text { N.A. } \\
\text { N.A. } \\
N . \Lambda . \\
<! \\
<1 \\
\vdots \\
-2\end{array}$ & $\begin{array}{l}14.3 \\
N . A . \\
\text { N.A. } \\
N . A . \\
47.2 \\
37.5 \\
\$ 1.0 \\
27.7 \\
25.5\end{array}$ & $\begin{array}{c}- \\
- \\
- \\
- \\
170.6 \\
113,6 \\
167.3 \\
58.2 \\
10.2\end{array}$ & $\begin{array}{l}0.49 \\
2.36 \\
2.74 \\
2.17 \\
N . A . \\
\text { N.A. } \\
N . A . \\
0.20 \\
0.2 .3\end{array}$ & $\begin{array}{l}= \\
= \\
\overline{15} \\
\bar{n}\end{array}$ \\
\hline $\begin{array}{l}\text { Bailing So } \\
\text { CHI-E1-35 } \\
\text { CH-E1-40 } \\
\text { CHI-EI-4I } \\
\text { CH-E1-42 } \\
\text { CHI-E1-43 } \\
\text { CHI-E1-80A } \\
\text { CH-E1-81A } \\
\text { CII-E1-98 } \\
\text { CHI-E1-99A }\end{array}$ & $\begin{array}{l}\text { ries } \\
06 / 05 / 87 \\
06 / 08 / 87 \\
06 / 08 / 87 \\
06 / 08 / 87 \\
06 / 08 / 87 \\
07 / 20 / 87 \\
07 / 20 / 87 \\
07 / 23 / 87 \\
07 / 23 / 87\end{array}$ & $\begin{array}{l}1630 \\
1430 \\
1530 \\
1659 \\
? \\
? \\
? \\
?\end{array}$ & $\begin{array}{l}3250 \\
2400 \\
2650 \\
3000 \\
3250 \\
2400 \\
2600 \\
2400 \\
2600\end{array}$ & $\begin{array}{l}-\overline{0.107} \\
0.198 \\
0.083 \\
0.291 \\
<0.05 \\
<0.05 \\
-0.103\end{array}$ & $\begin{array}{c}\vec{z} \\
= \\
\overrightarrow{2} \\
10.9 \\
\overrightarrow{3.99} \\
2.36\end{array}$ & $\begin{array}{l}\overrightarrow{1.540} \\
0.608 \\
0.610 \\
0.553 \\
0.303 \\
0.247 \\
\overrightarrow{0.046}\end{array}$ & $\begin{array}{l}- \\
0.212 \\
0.213 \\
0.208 \\
0.169 \\
0.276 \\
0.321 \\
\overline{0.208}\end{array}$ & $\begin{array}{l}\overline{0.175} \\
0.163 \\
0.106 \\
0.134 \\
0.162 \\
0.133 \\
\overline{0.115}\end{array}$ & $\begin{array}{l}7 \overline{74.0} \\
77.0 \\
71.8 \\
66.0 \\
68.9 \\
73.2 \\
8 \overline{87.6}\end{array}$ & $\begin{array}{c}- \\
19.02 \\
26.44 \\
24.74 \\
25.28 \\
20.58 \\
29.59 \\
28.70\end{array}$ & $\begin{array}{l}-5 \\
0.147 \\
0.101 \\
0.044 \\
0.003 \\
0.918 \\
0.461 \\
- \\
0.171\end{array}$ & $\begin{array}{l}7.13 \\
6.17 \\
1.80 \\
5.32 \\
14.0 \\
11.7 \\
\overline{9.59}\end{array}$ & $\begin{array}{l}N . \wedge \\
3.7 \\
3.4 \\
3.7 \\
2.8 \\
= \\
- \\
3.5\end{array}$ & $\begin{array}{l}N . A . \\
12.6 \\
12.0 \\
12.2 \\
20.4 \\
= \\
\overrightarrow{12.4}\end{array}$ & $\begin{array}{l}N . A . \\
<1 \\
<1 \\
<1 \\
<1 \\
= \\
= \\
11.7\end{array}$ & $\begin{array}{c}\text { N.A. } \\
33.4 \\
32.4 \\
32.4 \\
30.3 \\
= \\
- \\
\overline{37.2}\end{array}$ & $\begin{array}{l}-9 \\
79.4 \\
78.7 \\
49.4 \\
76.1 \\
= \\
= \\
=\end{array}$ & $\begin{array}{l}\text { N.A. } \\
1.16 \\
0.91 \\
0.16 \\
0.72 \\
= \\
\overline{0.11}\end{array}$ & $\begin{array}{l}2.5 \\
\ldots \\
= \\
= \\
= \\
\overline{0.22}\end{array}$ \\
\hline 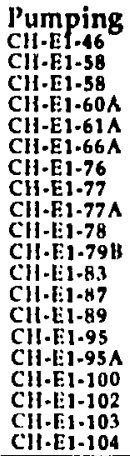 & $\begin{array}{l}\text { Series } \\
06 / 22 / 87 \\
06 / 23 / 87 \\
06 / 23 / 87 \\
07 / 07 / 87 \\
07 / 07 / 87 \\
07 / 07 / 87 \\
07 / 08 / 87 \\
07 / 08 / 87 \\
07 / 08 / 87 \\
07 / 09 / 87 \\
07 / 09 / 87 \\
07 / 21 / 87 \\
07 / 21 / 87 \\
07 / 22 / 87 \\
07 / 22 / 87 \\
07 / 22 / 87 \\
08 / 06 / 87 \\
08 / 06 / 87 \\
04 / 06 / 87 \\
08 / 06 / 87\end{array}$ & $\begin{array}{l}1200 \\
0900 \\
0900 \\
1300 \\
1400 \\
2100 \\
1700 \\
1900 \\
1900 \\
06 \$ 5 \\
1000 \\
1300 \\
1700 \\
1000 \\
1600 \\
1600 \\
1600 \\
1800 \\
1830 \\
1930\end{array}$ & $\begin{array}{l}2850 \\
2850 \\
2850 \\
2850 \\
2850 \\
2850 \\
2850 \\
2850 \\
2850 \\
2850 \\
2850 \\
2850 \\
2850 \\
2850 \\
2850 \\
2850 \\
2850 \\
2850 \\
2850 \\
2850\end{array}$ & $\begin{array}{l}\overline{0.005} \\
<0.005 \\
<0.005 \\
\overline{0.043} \\
\overline{0.054} \\
0.028 \\
\overline{0.091} \\
\overline{-} \\
\overline{0.026} \\
0.002 \\
0.041 \\
\overline{0.05} \\
\overline{0.014}\end{array}$ & $\begin{array}{l}\vec{z} \\
\overrightarrow{3.01} \\
\overrightarrow{2.92} \\
\overrightarrow{2.00} \\
\overrightarrow{2.79} \\
\overrightarrow{3.75} \\
\overrightarrow{-} \\
2.77 \\
3.04 \\
3.09 \\
\overrightarrow{2.70} \\
\overrightarrow{2.96}\end{array}$ & $\begin{array}{l}\overline{1.17} \\
1.12 \\
2.15 \\
\overline{5.64} \\
\overline{7.64} \\
7.64 \\
\overline{5.14} \\
\overline{-} \\
\overline{8.76} \\
9.51 \\
13.8 \\
\overline{2.16} \\
\overline{4.77}\end{array}$ & $\begin{array}{l}\overline{0.255} \\
0.251 \\
0.298 \\
\overline{0.309} \\
\overline{0} \\
0.288 \\
\overline{0.295} \\
\overline{0.281} \\
\overline{-} \\
\overline{0.312} \\
0.037 \\
0.313 \\
\overline{0.317} \\
\overline{0.313}\end{array}$ & $\begin{array}{l}\overline{0.086} \\
0.079 \\
0.177 \\
\overline{0.126} \\
\overline{0.102} \\
0.112 \\
\overline{0.099} \\
\overline{-} \\
\overline{0.111} \\
0.110 \\
0.109 \\
\overline{0.11} \\
\overline{0.099}\end{array}$ & $\begin{array}{c}7 \overline{75.3} \\
74.9 \\
76.3 \\
\overline{95.73} \\
\overline{95.33} \\
94.57 \\
\overline{80.02} \\
\overline{-} \\
94.50 \\
95.19 \\
97.02 \\
\overline{96.77} \\
\overline{88.5}\end{array}$ & $\begin{array}{c}-\overline{26.4} \\
26.2 \\
18.2 \\
38.2 \\
\overline{26.5} \\
26.7 \\
\overline{25.0} \\
- \\
23.5 \\
24.8 \\
25.7 \\
16.4 \\
16.5\end{array}$ & $\begin{array}{l}\overline{0.154} \\
0.195 \\
0.301 \\
\overline{0.206} \\
\overline{0.184} \\
0.167 \\
\overline{0.211} \\
\overline{-} \\
\overline{0.174} \\
0.186 \\
0.161 \\
\overline{0.191} \\
\overline{0.194}\end{array}$ & $\begin{array}{c}\overline{7.77} \\
7.87 \\
11.9 \\
\overline{10.8} \\
\overline{9.58} \\
10.2 \\
\overline{1.74} \\
- \\
6.72 \\
8.71 \\
6.04 \\
\overline{9.71} \\
\overline{7.43}\end{array}$ & $\begin{array}{l}\overline{4.4} \\
4.4 \\
4.5 \\
4.7 \\
4.5 \\
\overline{4.5} \\
4.5 \\
\overline{4.3} \\
- \\
4.6 \\
4.1 \\
4.3 \\
\overline{4.3} \\
\overline{4.3}\end{array}$ & $\begin{array}{c}\overline{12.7} \\
12.2 \\
12.7 \\
13.5 \\
12.8 \\
\overline{12.5} \\
12.5 \\
\overline{12.4} \\
\overline{=} \\
16.0 \\
13.5 \\
\mathbf{1 2 . 7} \\
\overline{13.0} \\
\overline{13.2}\end{array}$ & $\begin{array}{r}\overline{<1} \\
-1.5 \\
3.0 \\
13.7 \\
6.1 \\
\overline{3.6} \\
2.6 \\
\overline{2.6} \\
-.6 \\
14.1 \\
4.6 \\
22.7 \\
\overline{9.4} \\
\overline{7.3}\end{array}$ & $\begin{array}{c}\overline{30.9} \\
\mathbf{3 0 . 5} \\
\mathbf{3 4 . 0} \\
\mathbf{3 4 . 1} \\
\mathbf{3 3 . 4} \\
\overline{35.2} \\
\mathbf{3 5 . 0} \\
\overline{35.7} \\
\overline{-} \\
\mathbf{3 6 , 4} \\
\mathbf{- 3 7} \\
\mathbf{3 4 . 9} \\
\overline{34.1} \\
\overline{33,4}\end{array}$ & $\begin{array}{l}\overline{92.6} \\
100.7 \\
= \\
= \\
= \\
= \\
= \\
- \\
- \\
= \\
- \\
- \\
= \\
=\end{array}$ & $\begin{array}{l}1.32 \\
0.35 \\
- \\
\overline{-} \\
\overline{0} \\
0.46 \\
= \\
\overline{10.34} \\
0.34 \\
0.44 \\
0.17 \\
= \\
0.06 \\
0.04 \\
0.21 \\
0.16 \\
=0 \\
0.14\end{array}$ & $\begin{array}{l}\bar{z} \\
\overline{-} \\
\overline{16} \\
15 \\
16 \\
\bar{z} \\
14 \\
\overline{2.5} \\
\overrightarrow{5.0} \\
\overline{3.0} \\
\overline{-} \\
\overline{1.0} \\
\overline{-}\end{array}$ \\
\hline
\end{tabular}

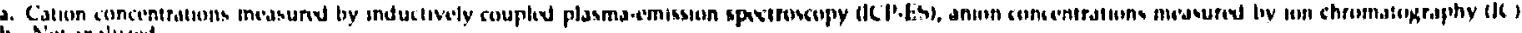
b Not,anolverd 


\section{Appendix C \\ Tests Fired Near or Below the Water Table}

This table lists all announced Events from July. 1957, through Ortaber, 1957, thal were israd belw the wale: table or just above it (within $25 \mathrm{~m}$ ). This information is from the Contanment Duts Buxs. tormerly called the LL. NL Containment Program Nuclear Tesi Efrects and Conlogit Datu Bux: No: entries are listed chronologicaliy and give the Event name, hole name, Evenl sponsor. datte et detonaturan. depth of burial (DOB), standing water level (SWL), and SWL qualifier (medsured or (xumlev).

DOB-This is the depth below the ground reference elevation shere the center ot the devce wias lucated. The description of the center of the device vanes somenhat from difterent so ares. The description is consistent for all LLVL data after 1970. Before that date, the nominal $c$ nter might vary from the bottom of the device can to the top of the device can energy center. The values in ahe wble alus reflect a mix of planned and as-bult numbers. Accuracy for older Events may be on the order of $=2 \mathrm{~m}$ Accuracy and definitions of LANL dat3 are not known.

SWL-This is the depth to the hydraulic head polenlial surface. Idealiy this is the ctepth to the statke water level table or the regional water table. The water table level is defind as the top of the wlurativ zone. Howev's, due to the layered nature of the rock and the structure ol this ares, there are nuny: locations at which the rock may be suturated. Also, careful measuremenis are meted over timw to determine that ihe observed level actually is statue.

About 100 measurements made at the NTS can be acturately described as indicatsng the depth to the* static water level. About 50 borcholes actually penetrated into the static sulurated zone, and careful mes. surements were made over time in these holes to accurately determine the SWL. About 20 cased borkholes had careful measurements made in them wilh packers in place. and these musuremenis neprosent separate saturated zones. There are a few holes that penetrated static suturated zoncs, but the measurements repreent composite values, i.e., a resultant water level due to all the formulsons thal ane open tos the borchole.

In many cases, data include measurements of levels that may nol actualiy be stutic. The wister level may be considered standing because of fluid invasion due to drilling, to rain or runoft water, or mounding of the static water level as a result of nearby tests. Frequently, for operational reasons. Ihere is not sufficient time to make d series of careful measurements. Thus the level measured may be "standing," but not necessasily static. Unfortunately there has been no altempt to differentiale these measuremenls Also, generally speaking, these are composite measurements, representing a value for all formutions open to the borchole. We strongly recommend that for grealest accuracy in determining the SWL in a particular location, all data available regarding the measurement be obtained from the data base.

Much more information is available on each Event than is given here-for example lithokgic and g(w)logic data from each borehole, as well as more detail on the events themselyes. For more information contact Gayle Pawloskı, Nuclear Test Containment Program, Earth Sciences Deparıment, LLNL. 
Table C-1. Data for all Tests fired below or near the water table, for the period 6r1957-101987.

\begin{tabular}{|c|c|c|c|c|c|c|}
\hline Event name & Hole name & Sponsor & Date & DOB, ft & SWL ft & SWLq! \\
\hline Bilby & U3CN & LANL & $09 / 13 / 63$ & 714300 & 503 & est. \\
\hline Wagtail & U3AN & LANL & $03 / 03 / 65$ & 749.600 & 509 & est. \\
\hline Cup & L9CB & LLNL & $03 / 26 / 65$ & 538.890 & 562 & est. \\
\hline Buteo & U20A & LANL & $05 / 12 / 65$ & 695.550 & 658 & meas. \\
\hline Cambric & USE & LLNL & $05 / 14 / 65$ & 294.740 & 213 & est. \\
\hline Diluted waters & L5B & LLNLDoD & $06 / 16 / 65$ & 192630 & 213 & est \\
\hline Bronze & L7F & LANL & $07 / 23 / 65$ & 530810 & 553 & est. \\
\hline Corduroy & L'10K & LL:NL & $12 / 03 / 65$ & 678.790 & 568 & meas. \\
\hline Buff & U3DH & LANL & $12 / 16 / 65$ & 500.410 & 520 & est. \\
\hline Lampblack & L7I & LANL & $01 / 18 / 66$ & 561.490 & $\mathbf{5 4 9}$ & est. \\
\hline $\operatorname{Rex}$ & U2OHE & LLNL & $02 / 24 / 66$ & 671.170 & 692 & meas. \\
\hline Chartreuse & L19D & LANL & $05106 / 66$ & 666750 & 662 & meas. \\
\hline Piranha & U7E & LANL & $05 / 13 / 66$ & 548.720 & 533 & est \\
\hline Dumont & L2T & LLNL & $05 / 19 / 66$ & 670.870 & 549 & est. \\
\hline Piledriver & C15A.01 & LANUDoD & $06 / 02 / 66$ & 462.690 & 457 & est. \\
\hline Tan & L7K & LANL & $06 / 03 / 66$ & 560.680 & 511 & est \\
\hline Puce & L3BS & LANL & $06 / 10 / 66$ & 485.550 & 504 & est. \\
\hline Halfbeak & L'19B & LANL & $06 / 30 / 66$ & $8 \pi 9.300$ & 645 & meas. \\
\hline Daiquiri & L7O & LANL & $09 / 25 / 66$ & 561.150 & 561 & est. \\
\hline Greeley & L20G & LLNL & $12 / 20 / 66$ & 1216.460 & 615 & meas. \\
\hline Agile & L2V & LL.NL & $02 / 23 / 67$ & 733.350 & 561 & est. \\
\hline Commodore & L2AM & LLNL & $05 / 20 / 67$ & 745.240 & 567 & est. \\
\hline Scotch & Ligas & LANL & $05 / 23 / 6 ?$ & 977390 & 672 & meas. \\
\hline Knickerbocker & L20D & LLNL & $05 / 26 / 67$ & 630.630 & 632 & meas. \\
\hline Zaza & $\mathrm{U4C}$ & LANZ & $09 / 27 / 67$ & 667.000 & 535 & est. \\
\hline Lanpher & L2X & LL:NL & $10 / 18 / 67$ & 715.060 & 552 & est. \\
\hline Cobbler & L7L & LANL & $11 / 08 / 67$ & 667.120 & 556 & est. \\
\hline Knox & L2AT & LLNL & $02 / 21 / 68$ & 644.800 & 549 & est. \\
\hline Stinger & U19L & LANL & $03 / 22 / 68$ & 667.760 & 640 & meas. \\
\hline Boxcar & U20I & LLNL & $04 / 26 / 68$ & 1165.860 & 580 & meas. \\
\hline Rickey & U19C & LANL & $06 / 15 / 68$ & 683.280 & 707 & meas. \\
\hline Chateaugay & U20T & LLNL & $06 / 28 / 68$ & 607.230 & 632 & est. \\
\hline Sled & U19I & LANL & $08 / 29 / 68$ & 728.580 & 667 & meas. \\
\hline Noggin & U9BX & LLNL & $09 / 06 / 68$ & 582.170 & 558 & est. \\
\hline Benham & L20C & LLNL & $12 / 19 / 68$ & 1402.080 & 641 & meas. \\
\hline Blenton & L7P & LANL & $04 / 30 / 69$ & 557.730 & 553 & est. \\
\hline Thistle & U7T & LANL & $04 / 30 / 69$ & 560.470 & 578 & est. \\
\hline Purse & L20V & LLNL & $05 / 07 / 6^{4}$ & 598.780 & 601 & meas. \\
\hline Jorum & L20E & LLNL & $09 / 16 / 69$ & 1160.890 & 556 & meas. \\
\hline Pipkin & L20B & LLNL & $10 / 08 / 69$ & 623.620 & 640 & esL \\
\hline Calabash & L2AV & LLNL & $10 / 29 / 69$ & 6.24 .840 & 578 & est. \\
\hline Grape A & L7S & LANL & $12 / 17 / 69$ & 550.670 & 568 & est. \\
\hline Grape B & L7V & LANL & $02 / 04 / 70$ & 554.030 & 565 & est. \\
\hline Shaper & L7R & LANL & $03 / 23 / 70$ & 560.440 & 549 & est. \\
\hline Handley & L20M & LLNL & $03 / 26 / 70$ & 1209.000 & 387 & meas. \\
\hline Tijeras & L7Y & LANL & $10 / 14 / 70$ & 560.620 & 543 & meas. \\
\hline Carpetbag & L2DG & LLNL & $12 / 17 / 70$ & 661.700 & 576 & est. \\
\hline
\end{tabular}


Table C-1 (continued).

\begin{tabular}{|c|c|c|c|c|c|c|}
\hline Event name & Hole name & Sponsor & Date & DOB & SWL, ft & SWLql \\
\hline Miniata & U2BU & LLNL & $08 / 02 / 71$ & 528830 & 491 & meas. \\
\hline Algodones & U3JN & LANL & $0218 / 7$ & 520.610 & 501 & est. \\
\hline Monero & U3JQ & LANL & $05 n 9 / 72$ & 537.350 & 526 & meas. \\
\hline Oscuro & U7Z & LANL & $09 / 21 / 72$ & 560.220 & $\mathbf{5 2 1}$ & est. \\
\hline Miera & U7AD & LANL & $03 / 08 / 73$ & 568.760 & 550 & est. \\
\hline Angus & U3JG & LANL & $01 / 25 / 73$ & 452930 & 472 & meas. \\
\hline Starwort & U2BS & LLNL & $04 / 26 / 73$ & 563.880 & 526 & meas. \\
\hline Almendro & U19V & LANL & $06 / 06773$ & 1063.750 & 686 & meas. \\
\hline Latir & U4D & LANL & $02 / 2974$ & 640.990 & $\mathbf{5 0 0}$ & est. \\
\hline Escabosa & U7AC & LANL & $07 / 1074$ & 609.990 & 545 & est \\
\hline Portmanteau & U2AX & LLNL & $08 / 30 / 74$ & 655.290 & 585 & meas. \\
\hline Stanyan & U2AW & LLNL & $09 / 26 / 74$ & 572990 & 553 & meas. \\
\hline Topgallant & U4E & LANL & $02 / 2375$ & 713.200 & 515 & meas. \\
\hline Cabrillo & U2DR & LLNL & $03 / 07 / 75$ & 600.500 & 567 & meas. \\
\hline Obar & U7AG & LANL & $04 / 30 / 75$ & 569.000 & 521 & meas. \\
\hline Tybo & U20Y & LLNL & $05 / 14 / 75$ & 765.000 & 630 & meas. \\
\hline Mizzen & U7AH & LANL & $06 / 00 / 75$ & 637.000 & 515 & meas. \\
\hline Stilton & U20P & LLNLJoD & $06 / 03 / 75$ & 731.500 & 280 & meas. \\
\hline Mast & U19U & LANL & $06 / 19 / 75$ & 911300 & 666 & meas. \\
\hline Camembert & U19Q & LLNL & $06 / 26 / 75$ & 1310.600 & 668 & meas. \\
\hline Kasseri & U20Z & LLNL & $10 / 28 / 75$ & 1265000 & 628 & meas. \\
\hline Inlet & U19F & LANL & $11 / 20 / 75$ & 819.000 & 200 & meas. \\
\hline Chiberta & U2EK & LLNL & $12 / 20 / 75$ & 716.000 & 536 & meas. \\
\hline Muenster & U19E & LLNL & $01 / 03 / 76$ & 1452400 & 676 & meas. \\
\hline Esrom & U7AK & LLNL & $02 / 0476$ & 655.300 & 523 & meas. \\
\hline Keelson & U7AI & LANL & $02 / 04 / 76$ & 640.000 & 498 & meas. \\
\hline Fontina & U20F & LLNL & $02 / 12 / 7$ & 1219.000 & 595 & meas. \\
\hline Cheshire & U20N & LLNL & $02 / 14 / 76$ & 1167.000 & 625 & meas. \\
\hline Estuary & U19G & LANL & $03 / 09 / 76$ & 868.100 & 627 & meas. \\
\hline Colby & U20AA & LLNL & $03 / 14 / 76$ & 1273.400 & 571 & meas. \\
\hline Pool & U19P & LANL & $03 / 17 / 76$ & 879.300 & 690 & meas. \\
\hline Strait & U4A & LANL & $03 / 17 / 76$ & 780.300 & 506 & meas. \\
\hline Billet & U7AN & LANL & $07 / 27 / 76$ & 635.500 & 503 & meas. \\
\hline Banon & U2DZ & AWRE/LLNL & $02 / 26 / 76$ & 536.400 & 548 & meas. \\
\hline Rudder & U7AJS & LANL & $12 / 28 / 76$ & 640.000 & 520 & meas. \\
\hline Marsilly & U2EL & LLNL & $04 / 05 / 77$ & 690.000 & 541 & meas. \\
\hline Bulkhead & U7AM & LANL & $04 / 27 / 77$ & 594.300 & 532 & meas. \\
\hline Crewline & U7AP & LANL & $05 / 25 / 77$ & 563.900 & 503 & meas. \\
\hline Strake & U7AE & LANL & $02 / 04 / 77$ & 518.200 & 541 & meas. \\
\hline Scantling & $\mathbf{U} 4 \mathbf{H}$ & LANL & $08 / 19 / 77$ & 701.000 & 511 & meas. \\
\hline Sandreef & U7AQ & LANL & $11 / 09 / 77$ & 701.000 & 503 & meas. \\
\hline Farallones & U2FA & LLNL & $12 / 14 / 77$ & 668.000 & 554 & meas. \\
\hline Reblochon & U2EN & LLNL & $02 / 23 / 78$ & 658.400 & 540 & est. \\
\hline Iceberg & U4G & LANL & $03 / 23 / 78$ & 640.000 & 507 & meas. \\
\hline Transom & U4F & LANL & $05 / 10 / 78$ & 640.000 & 507 & meas. \\
\hline Lowball & U7AV & LANL & $07 / 12 / 78$ & 563.900 & 501 & meas. \\
\hline Panir & U19YS & LLNL & $08 / 31 / 78$ & 681.000 & 645 & est. \\
\hline
\end{tabular}


Table C-1 (continued).

\begin{tabular}{|c|c|c|c|c|c|c|}
\hline Event name & Hole name & Sponsor & Date & DOB & SWL, ft & SWLq1 \\
\hline Rummy & U7AU & LANL & $09 / 20 / 78$ & 640000 & 504 & est \\
\hline Quargel & U2FB & AWRE/LLNL & $11 / 18 / 78$ & 512000 & 509 & meas. \\
\hline Farm & U20AB & LLNL & $12 / 1678$ & 689000 & 619 & est \\
\hline Quinella & U4L & LANL & $02 / 08 / 79$ & 579.100 & $\mathbf{5 1 2}$ & est. \\
\hline Pepato & U20AD & LLNL & $06 / 11 / 79$ & 601000 & 579 & meas. \\
\hline Hearts & $\mathbf{U} \mathbf{4 N}$ & LANL & $09 / 06 \sqrt{79}$ & 640000 & 507 & meas. \\
\hline Pyramid & U7BE & LANL & $0416 / 80$ & 579.100 & $\mathbf{5 4 0}$ & meas. \\
\hline Colwick & U20AC & LLNL & $04 / 26 / 80$ & 633.000 & 630 & est \\
\hline Kash & U20AF & LLNL & $06 \sqrt{12} / 80$ & 645000 & 602 & est \\
\hline Tafi & U20AE & LLNL & $07 / 25 / 80$ & 680000 & 607 & meas. \\
\hline Baseball & U7B A & LANL & 01/15/81 & 563.900 & 512 & meas. \\
\hline Rousanune & UAP & LANL & $11 / 2 / 81$ & 518200 & 495 & est \\
\hline Jornada & U4J & LANI. & $01 / 28 / 82$ & 640000 & 507 & est. \\
\hline Molbo & U20AG & LLNL & $02 / 2 / 82$ & 638.000 & 614 & meas. \\
\hline Bouschet & U3LA & LANL & $05 / 07 / 82$ & 563.900 & 500 & est. \\
\hline Atrisco & U7BP & LANL & $02 / 05 / 82$ & 640.100 & 538 & meas. \\
\hline Borrego & U7BR & LANL & $09 / 29 / 82$ & 563.900 & 501 & meas. \\
\hline Turquoise & U7BU & LANL & $04 / 1483$ & 533.000 & 500 & est \\
\hline Chancellor & U19AD & LANL & $09 / 01 / 83$ & 625000 & 647 & meas. \\
\hline Techado & U40 & LANL & $09 / 22 / 83$ & 533.400 & 500 & est. \\
\hline Tortugas & U3GG & LANL & 03/02/R4 & 640.100 & 497 & meas. \\
\hline Mundo & U7BO & LANL & 05/01/84 & 567000 & 558 & est. \\
\hline Caprock & U4Q & LANL & $05 / 31 / 84$ & 600.000 & 500 & est. \\
\hline Kappeli & U20AM & LLNL & $07 / 25 / 84$ & 640.000 & 652 & meas. \\
\hline Breton & U4AR & LLNL & $09 / 13 / 84$ & 483.000 & 505 & est \\
\hline Hermosa & U7BS & LANL & ovord85 & 640.100 & 506 & meas. \\
\hline Towanda & U19AB & LANL & $05 / 02 / 85$ & 664.500 & 614 & meas. \\
\hline Salut & U20AK & LLNL & $06 / 12 / 85$ & 608.000 & 622 & meas. \\
\hline Serena & U20AN & LLNL & $07 / 25 / 85$ & 597.000 & 606 & meas. \\
\hline Kinibito & U3ME & LANL & $12 / 05 / 85$ & 579.100 & 488 & est. \\
\hline Glencoe & U4I & LANL & $03 / 22 / 86$ & 609.600 & 522 & est. \\
\hline Jefferson & U20AI & LLNL & $0-2 / 22 / 86$ & 609.000 & 625 & meas. \\
\hline Darwin & U20AQ & LLNL & $06 / 25 / 86$ & 549.000 & 574 & meas. \\
\hline Cybar & U19AR & LANL & $07 / 17 / 86$ & 627.900 & 645 & meas. \\
\hline Aleman & U3KZ & LANL & $09 / 11866$ & 502.900 & 500 & est \\
\hline Labquark & U19AN & LLNL & $09 / 30 / 86$ & 616.000 & 641 & meas. \\
\hline Belmont & U20AS & LLNL & $10 / 16 / 86$ & 605.000 & 613 & meas. \\
\hline Gascon & UAT & LANL & $11 / 14 / 86$ & 593.140 & 505 & est. \\
\hline Bodie & U20AP & LLNL & $12 / 13 / 86$ & 635.000 & 652 & meas. \\
\hline Hardin & U20AV & LLNL & $04 / 30 / 87$ & 625.000 & 632 & meas. \\
\hline Tahoka & U3MF & LANL & $08 / 13 / 87$ & 640.100 & 493 & est. \\
\hline Borate & U2GE & LLNL & $10 / 23 / 87$ & 542.500 & 567 & meas. \\
\hline
\end{tabular}




\section{Appendix D}

\section{Tentative Proposal from Lamont-Doherty Geological Observatory of Columbia University for Work in the HRMP}

After preliminary discussions with Dr. H. J. Simpson Jr. at Lamont-Doherty, it seems that some of their work and experience in the study of natural radionuclides in ground and surface water would io applicable to the HRMP program at the NTS. We asked him to write an informal proposal of his ideas fur our consideration. The following is the result and for the moment should only be considend as suggestions for the types of work that could be done. We would like Dr. Simpson to participate in the program as we feel his knowledge and experience would be valuable, and it would also help us include academic researchers in the program, a policy encouraged by the DoE. We will probably develop sone type of cooperative research project for FY88, when we have more definite information on our budget.

Title of Proposal: Natural Radionuclide Activity Transport Processes and Rates in NTS Groundwaters Compared with Those for Detonation Nuclides

Migration of radionuclides from waste packages placed in underground repositories can be projected by a variety of approaches. Tracer experiments, especially on a large scale, offer one of the most powerful verification tools available for model calculations. However, for many environnwents in whtch large-scale tracer experiments are not practical, information can be gained from the transprrt buhasior ol natural radionuclides.

The ongoing Radionuclide Migration Project at the NTS offers an ideal opportunity to link understanding of transport processes for natural and detonation radionuclides with the goal of improving verification of model calculations for waste package radionuclides. We propose to add a new component of measurements to current activities at the NTS to help provide this linkage.

Our initial effort would be made in cooperation with planned sampling during early tall 1987 at UE20n-1. We would analyze samples of water shipped to LDGO for isotopes of uranium, thorium, radium, and other daughter products of the U-238, U-235, Th-232 parent nuclides. If feasible, we would also analyze for natural radionuclides in splits of samples passed through the filtration cascade (ultra-filter) by the LLNL group to provide direct comparison with the colloid speciation distributions derived for detonation nuclides.

During previous research at the WIPP site and nearby oil and gas froduction wells, we observed uranium and therium series radionuclide distributions that clearly demonstrated extremely large effects of redox conditions on radionuclide transport, even for elements that are present in only a single oxidation state, as well as strong indications of colloidal associations for both uranium and thorium. Although the redox and other chemical characteristics of these New Mexico ground waters contrast greatly with those at the NTS, the conclusions derived from the natural radionuclide distributions there are sufficiently similar to those derived from filtration studies on detonation nuclides at the NTS to suggest :he need for more intensive investigation.

We would use a combination of laboratory and counting terhniques developed over several decades of rescarch on marine systems as well as other natural water radionuclide studies to make the measurements proposed here. Our intention would be to use equipment at LDGO for alpha, beta, and gamma counting for our initial measurements. As the work progressed, we would plan to initiate measurements of other nuclides that require either separations and/or couniing at the sampling site, using counting equipment at the NTS or transported temporarily from LDGO.

The sampling at the NTS and shipping of water required for this research effort would be a relatively small perturbation of activities already planned for the Radionuclide Migration Program. Several oth، $r$ 
directions of research also would be pursued if they were deemed promising and not already planned by other groups. These would include:

1. Collection of a long time series of measurements of detonation products, such as tritium and a few gamma-emitting nuclides, at UE20n-1 to provide detailed data on the variability of radionuclide activities pumped from the groundwater system. For Irilium, and other easily measured nuclides, these cnuld be sampled and analyzed on a daily basis.

2. Collection of samples for natural radionuclide measurements from the "formation" location in the reentry hole. These data would be useful for comparison with the detonation nuclide data already obtained.

3. Collection of data on rare gas radionuclides in NTS groundwaters near the Cheshire site. We have an active research group at LDGO cumenly analyzing $\mathbf{K r}-85$ in sea water for ocean mixing studies, and a history of more than two decades of research involving $\mathrm{Rn-222}$ in natural waters.

4. Analysis of drill core cuttings from post detonation holes near the Cheshire site for uranium and thorium series nuclides for comparison with the groundwater data. Both absolute concentrations and nuclide ratios in these rhyolites would provide critical complementary information concerning radionuclide transport processes. Disequilibria observed through these measurements on rock samples could yicld insights about transport processes orer much longer periods than those accessible from the ground water samples alone.

5. Characterization of some nuclide binding and other properties of colloidal materials separated from unfiltered water samples at the NTS. Although the organic carbon components of NTS ground waters are relatively low, the observations we have made in New. Mexico suggest that cven small amounts of organic compounds may be important in radionuclide transport. 